\title{
STUDIES ON THE EGG MASSES AND LARVAL DEVELOPMENT OF SOME PROSOBRANCHS FROM THE GULF OF MANNAR AND THE PALK BAY*
}

\author{
By A. V. NATARAJAN \\ (Government of India Senior Research Scholar in Marine Biology, Central Marine Fisheries \\ Research Station, Mandapam, S. India) \\ Received April 8, 1957 \\ (Communicated by Dr. N. K. Panikkar, F.A.sc.)
}

CONTENTS

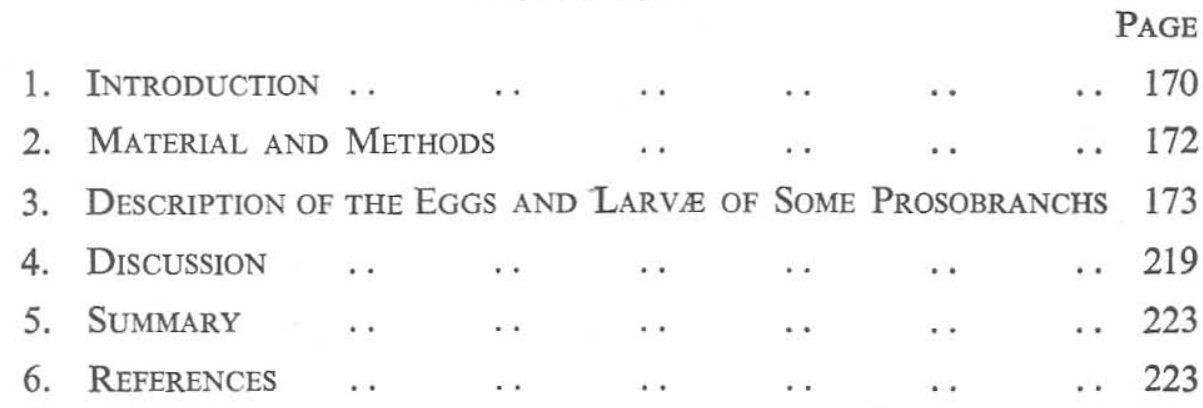

\section{INTRODUCTION}

IN recent years our knowledge of the eggs and larvæ of marine gastropods has increased considerably. The investigations of Lebour (1937) and Thorson (1946) have added much to our knowledge of the eggs and larvæ of prosobranchs from Plymouth and Danish waters. Franc's (1948) investigations at Algiers and Banyuls supplement at many points the work of Lebour and Thorson. The breeding habits of this group of molluscs at Bermuda as well as in East Greenland and Iceland have also been studied respectively by Lebour (1945) and Thorson (1935, 1941).

In the Indo-Pacific area the breeding habits, egg masses and larval development of some prosobranchs have been studied by Risbec (1928, 1931, 1932, 1935) and Petit and Risbec (1929) from the New Caledonian coast, by Thorson (1940) from the Iranian Gulf, by Ostergaard (1950) from the Hawaiian coasts, and Habe $(1944,1953,1955)$ and Amio (1950) from the Japanese waters. Lamy (1928) has summarised the older literature on the

* From the Thesis approved for the degree of Master of Science of the Annamalai University. Published with the permission of the Chief Research Officer, Central Marine Fisheries Research Station, Mandapam Camp, S. India. 


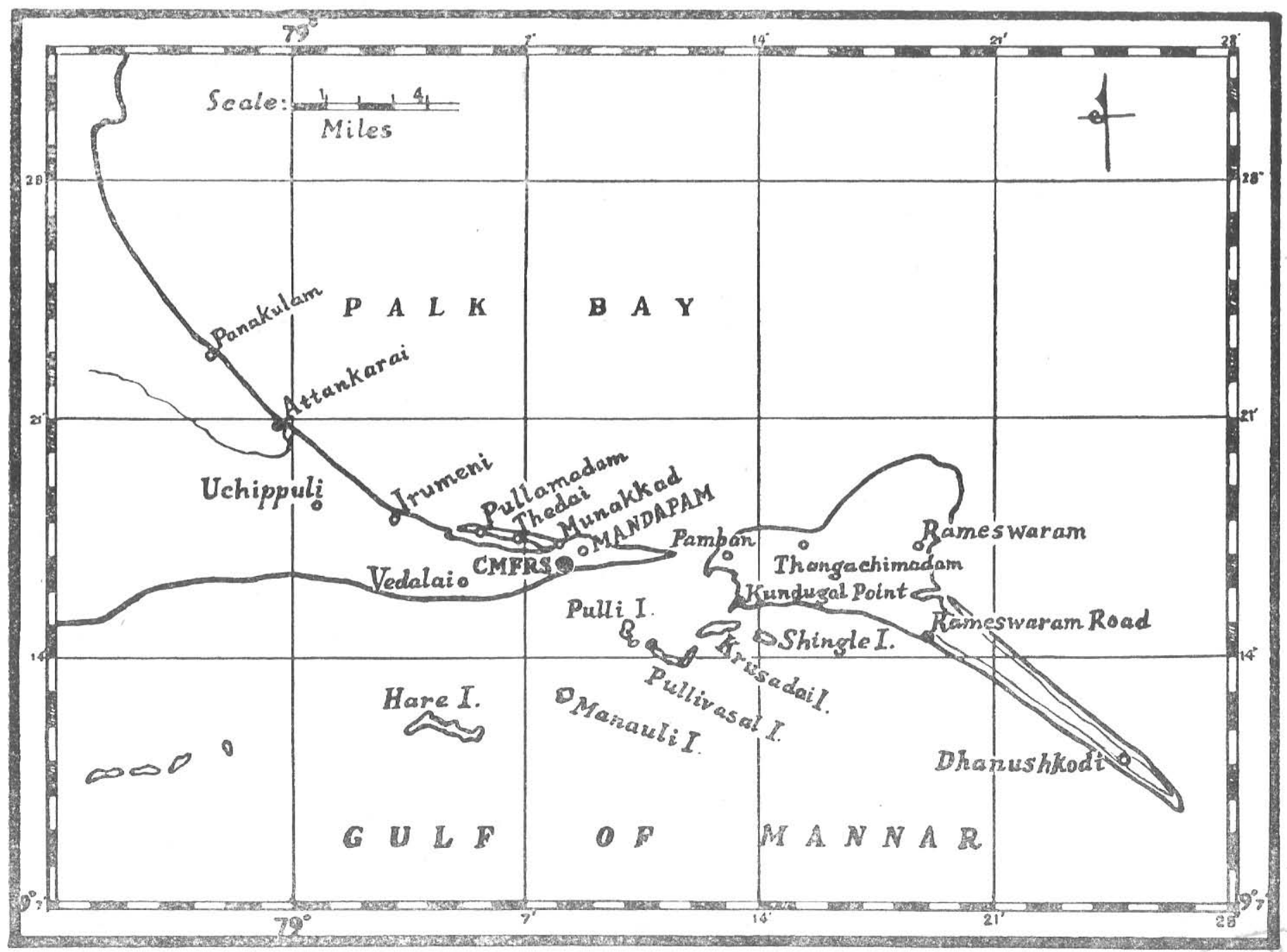

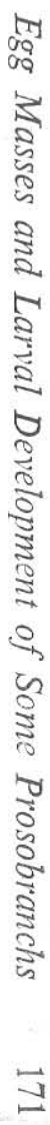

MAP 1. Showing vicinities of Mandapam wherefrom the prosobranch egg masses were collected. 
tropical prosobranch egg masses and Knudsen (1950) described a large number of them from West Africa.

No concerted attempt appears to have been made so far from any locality in India to study the breeding habits of the marine gastropod molluscs. Hornell (1921) has made casual reference to eight egg masses and Gravely (1942) to twelve, some of which have not been ascribed to any definite species. A few details are also available on the egg masses of Thais carinifera (Annandale and Kemp, 1916), Potamides cingulatus and Natica (Panikkar and Aiyar, 1939), Tonna sp. (Panikkar and Tampi, 1949) and Thais bufo (Chari, 1950) and on larval development of Xancus pyrum (Chidambaram and Unny, 1947).

From the above résumé it is clear that studies on the breeding habits and the larval development of marine prosobranchs have not received much attention from Indian workers. Krusadai, Pamban and Mandapam are well known for their rich molluscan fauna and it was suggested to me that the breeding biology of them will be of considerable scientific interest. The present work may be said to follow broadly the pattern of investigations of Risbec (1931, 1932, 1935) from New Caledonia, Thorson (1940) from Iran, Rasmlssen (1944, 1951) from Denmark, Lebour (1945) from Bermuda, Knudsen (1950) from West Africa and Ostergaard (1950) from Hawaii. Thiele's Handbuch der systematischen Weichtierkunde (Jena, 1931) and Satyamurti's (1952) Mollusca of Krusadai Island have been generally followed for systematic classification and nomenclature of the forms dealt with in this paper.

The work reported here is the result of the investigations of over three years from 1952-55 carried out at the Central Marine Fisheries Research Station, Mandapam, S. India. The writer expresses his gratitude to Dr. N. Kesava Panikkar for suggesting this problem as well as for his guidance, suggestions and advice throughout the course of this work. Thanks are also due to Shri K. Virabhadra Rao for his willing help and suggestions during the progress of this investigation; to the Government of India for the award of a scholarship; and to Shri K. G. Nambiar for the photographs included in this paper.

\section{Material AND Methods}

The material was collected from the Gulf of Mannar and the Palk Strait at different places, viz., Krusadai Island, Shingle Island, Pulli Reef, Kundugal Point, Pamban, Munakkad, Vedalai, Seeniyappa Dharuga, Mandapam, Rameswaram Road and Pudumadam (Map 1). The material examined comprises spawn masses, embryos and free swimming veligers of 32 prosobranchs, 
Plankton samples from the Palk Bay and the Gulf of Mannar were examined periodically. The spawn masses are usually found on the undersurfaces of the stones, boulders or upon the algæ, dead shells, corals and crevices of the rocks. The mud-flats at Kundugal Point form an ideal substratum for the characteristic egg ribbons of Natica. Some of these spawn masses themselves serve for the attachment of the spawn of others. The adult animals were kept in aquaria to observe the spawning habits. This also helped in corroborating the provisional identification of the egg masses obtained from natural habitats. Breeding season was determined as far as possible for each species under investigation.

Salinity and temperature were noted during spawning periods wherever it was possible. The chlorinity of samples of sea-water was estimated by the Mohr titration with the silver nitrate using potassium chromate as indicator and following an experimental procedure similar to the one described by Harvey (1945). By referring to Knudsen's tables (1901) the salinity, i.e., parts by weight of sea-water was read off corresponding to the estimated chlorinity.

Magnesium salts were found quite useful in narcotising the larvæ for which the following procedure was followed. Filtered sea-water was taken in a medium sized watch-glass and a few larvæ were transferred to it. Saturated solution of magnesium chloride or magnesium sulphate (both were found equally effective) were added drop by drop at intervals of 4-5 minutes. Usually 3-7 drops were found sufficient to narcotise the larvæ. As soon as narcotisation was complete the larvæ were transferred to a cavity slide and sketched. Menthol was also found effective in some cases.

The material was mostly examined and sketched in the living condition. The larvæ were sketched with camera lucida and the measurements taken with the help of an ocular micrometer. The named collections, preserved in $5 \%$ formalin, are now kept in the museum of the Central Marine Fisheries Research Station, Mandapam Camp.

Various terms, egg ribbon, egg sheet, egg case, and egg cluster have been used in this paper to denote the spawns of the prosobranchs according to their characteristic features, but the term, egg mass, is used to denote all types.

\section{Description of the Eggs and Larve of Some Prosobranchs}

\section{Neritida}

The egg capsules of the genus Nerita have been described for a number of species (Lamy, 1928; Risbec, 1932, 1935; Andrews, 1935; Lebour, 1945; 
Knudsen, 1950). It has been observed that the walls of the egg capsules in Neritidæ contain small mineral particles. In Nerita these paricles were found to consist of spherulites of calcium. No account is available on the breeding babits of Nerita from Indian waters.

Nerita albicilla Linné (Figs. 1-6).- The egg capsules belonging to Nerita have been collected from Shingle Island attached to stones and dead corals in the month of February, April, May, July, August and September. The only species that appears to be common in the area examined is $N$. albicilla to which species therefore the present egg capsules are referred.

The egg capsules which are firmly glued to the substrata are white and hardy and are round or oval in shape. They are plano-convex, and each capsule consists of a membranous base and calcareous convex top or lid. The largest diameter of the capsule in 14 specimens examined is $1 \cdot 87-2.48 \mathrm{~mm}$. The lid consists of numerous cup-shaped structures (circular in outline), placed close to each other and each consisting of a spherical body inside.

The eggs, which are spherical and white, measure each $0.116 \mathrm{~mm}$. across. They are suspended in a mucous fluid. The number of eggs per capsule is 121-85. In the present case it is not possible to give the time of development from the egg to the hatching stage. Risbec (1932) found that after 52 days the veligers of $N$. albicilla from New Caledonia were still unhatched but moving freely inside the capsule.

The newly hatched veliger has a shell of one whorl which is slightly pitted in appearance and measures $0 \cdot 150-0 \cdot 167 \mathrm{~mm}$. across the shell. The velum is bilobed, colourless and is bordered with long cilia. Eyes are black and prominent. Tentacles could not be seen. Foot is ciliated and greenish. It also shows reddish brown pigments on either side at the base of the foot. Risbec finds vermillion pigments in the New Caledonian species. Operculum is present. Otocysts are not clear. Liver is pale yellow. The larva thrived at the laboratory for two days.

\section{Potamididce}

Panikkar and Aiyar (1939) have given an account of the spawn of Potamides cingulatus (Cerithidea fluviatilis) from Madras and Habe (1955) that of Cerithidea djadjariensis and C. rhizophorarum from Japan.

Cerithidea fluviatilis (Potiéz and Michaud) (Photos 1 \& 2 and Figs. 7-9).-No details appear to be available on the structure of the egg mass or larvæ of this species except for the observation of the spawn masses of this species at Madras by Panikkar and Aiyar. Sadasivan (1948) has made detailed studies on the rate of growth, the duration of the breeding period and the age at matırity of this species, also from Madras. 
This species is very well represented at Kundugal Point wherein large areas are strewn with large numbers of live as well as dead shells, the latter quite commonly being occupied by hermit crabs. This species does not frequent the reefs exposed to the open surf. Satyamurti (1952) has also recorded them at Pamban and Krusadai Island.

The spawn masses of this species were found in the January-September period. Quite often they are found on the muddy substratum; some are attached to the inner or outer surface of the Natica egg ribbons as well as to dead or live shells, chiefly bivalves and seaweeds. The eggs are laid in narrow gelatinous strings of a width of $0.30-0.50 \mathrm{~mm}$. The egg string is thrown into a series of more or less identical folds placed compactly side by side into a ribbon-like structure. The egg ribbons, in the old state, do not show the egg strings clearly. They are white and are of a width varying from $2 \cdot 3-2 \cdot 7 \mathrm{~mm}$. and a length from $8 \cdot 4-16 \cdot 3 \mathrm{~cm}$. They in turn may be thrown into folds, regular or irregular. The gelatinous part of the ribbon is colourless and transparent and the eggs are quite clearly seen through it. The egg is yellowish white and measures $0 \cdot 133-0.150 \mathrm{~mm}$. across. This is surrounded by a thin-walled egg covering (capsule) measuring $0.233-0.283 \mathrm{~mm}$. The egg covering may be round or oval in outline. On an average an egg ribbon contains about 4,800 eggs.

Some of the adult specimens kept at the laboratory in a glass trough in mid-December 1953 spawned on the 10th January 1954. The spawn was glued to the side of the glass trough very near the surface of the water. The temperature and salinity at the time of spawning were $25 \cdot 50^{\circ} \mathrm{C}$. and $31 \cdot 18 \%$ respectively.

It took about 4 days from the time the eggs were laid for the larvæ to hatch. The embryo at the time of hatching measures about $0.200 \mathrm{~mm}$. across the shell which is rough and semi-transparent. The outer lip of the shell, as soon as the embryo hatches out as veligers, begins to show transpiral striations and is slightly extended forward in the middle.

The umbilicus is slightly pinkish purple. The larva is pale yellow. The velum is thick and bilobed. The eyes, tentacles and otocysts are present and the foot is ciliated. The alimentary tract and liver are yellow. The heart beat could be seen through the shell.

The spawn masses collected from the field do not show normal development under laboratory conditions.

\section{Cerithiida}

The breeding habits of a few species of Cerithium are known in the literature (Lo Bianco, 1888; Risbec, 1935; Lebour, 1945). The members of the 




FIGs, 1-18 
genus Bittium also appear to have spawns of similar nature ( $c f$. Meyer and Mobius, 1872; Thorson, 1946).

Cerithium mor us Lamarck (Photos $3 \& 4$ and Figs. 10-18).-The breeding habits of this species are described here for the first time. This species is abundantly represented on the reefs in the Palk Bay between Munakkad and Mandapam. Living and dead shells of this species are found quite commonly in Pamban in shallow areas and it appears to be a very prolific breeder during its spawning season. From the number of spawn masses collected in the field it is clear that the breeding starts about the middle of January, reproductive activity being somewhat low during January and February (the mean temperature and salinity for the months being $24 \cdot 4^{\circ} \mathrm{C}$., $27 \cdot 41 \%$ and $24 \cdot 7^{\circ} \mathrm{C}$., $30.03 \%$ respectively). Large number of spawns have been encountered in March (mean temperature $27 \cdot 1^{\circ} \mathrm{C}$., mean salinity $32 \cdot 74 \%$ ). It is only in April (mean temperature $28.6^{\circ} \mathrm{C}$., mean salinity $33.69 \%$ ), May (mean temperature $27^{\circ} \mathrm{C}$., mean salinity $34.39 \%$ ) and June (mean temperature $27 \cdot 2^{\circ} \mathrm{C}$., mean salinity $34 \cdot 39 \%$ ) that the spawning is very active with the climax probably in May. There is a steep decline in spawning in July (mean temperature $29 \cdot 9^{\circ} \mathrm{C}$., mean salinity $34 \cdot 8 \%$ ) which almost comes to an end by the last week of July. The species seems to have no preference for any specific substratum as the spawn masses have been collected from corals, stones, seaweeds, dead shells, etc.; they also spawn on the glass sides of the aquarium, glass troughs and even finger bowls. In the aquarium the spawn masses were laid close to the surface of water as well as the middle and the base of the glass sides. In some, part of the spawn mass is completely clear of the water, the rest being just immersed.

The eggs are laid in a long string of a width of $0 \cdot 25-0.41 \mathrm{~mm}$. The egg ribbon is formed of this egg string in much the same way as in C. fluviatilis. It is $60-185 \mathrm{~mm}$. long, $1 \cdot 72-2 \cdot 75 \mathrm{~mm}$. broad and $0.45 \mathrm{~mm}$. thick and is surrounded by a gelatinous matrix, which is whitish or pale yellow in colour. The latter is quite transparent making the eggs visible. Two specimens were observed as soon as the spawning began. One of them (length $19 \mathrm{~mm}$. and largest breadth $9 \mathrm{~mm}$.) took about $2 \frac{1}{4}$ hours to complete a ribbon of a length of $75 \mathrm{~mm}$.; the other (length $18 \mathrm{~mm}$. and largest breadth $8 \mathrm{~mm}$.) took 1 hour and 50 minutes to complete $70 \mathrm{~mm}$. An egg ribbon contains on an average 9,100 eggs. The disposition of the eggs in some ribbons are close while in others they are distantly placed. Thus two egg ribbons with similar dimensions may differ in their egg numbers. The eggs are yellowish white and measure each about $108-16 \mu$ in diameter and are each surrounded by an egg covering of a diameter of $150-67 \mu$. The egg coverings are spherical, oval 
or oblong in shape. They are flexible and transparent and usually do not touch each other and are placed at a distance of $12-18 \mu$ from one another.

It takes just more than 3 days for the eggs to hatch out as free swimming veligers. The embryos in the hatching stage are yellow in colour and show smooth, colourless, sculptureless and fairly transparent shells each of which measures about $0 \cdot 150-0 \cdot 167 \mathrm{~mm}$. across. The velum is bilobed and shows long cilia on the margin. Foot, operculum and otocysts are present. The liver is yellow.

The day-old veliger measures $0.200 \mathrm{~mm}$. across the shell which shows slow changes to brown colour. The outer lip begins to show a few spiral striations besides the transpiral striations and is extended in the middle to form a beak-like structure. The umbilicus is slightly purplish in colour. The bilobed velum is well developed, but the lobes tend to show slight disparity in size. The velum measures about $0.200 \mathrm{~mm}$. There is a sub-velum with small cilia. The eyes are black and distinct. The tentacles are stout, broad and well developed. The foot is pale yellow and is ciliated. The operculum and otocysts are present. The liver is pale yellow. The heart beat is visible.

The four-day old veliger shows further increase in the size of the larval shell. The latter is brown and measures about $0.217 \mathrm{~mm}$. across. Spiral lines have become more prominent besides the transpiral striations. The outer lip of the shell is further extended and slightly inflexed. The velum now measures $0.288 \mathrm{~mm}$. across. The disparity in lobes is also more pronounced. The sub-velum is more prominent. The larvæ lived at the laboratory for 5 days. The well-developed velum of the veliger points to a long pelagic period in its life-history.

Cerithium sp. (Photos $5 \& 6$ and Figs. 19-22).-Gelatinous white masses characteristic of Cerithium were found attached to stones, corals, shells, seaweeds, etc., in between tide marks at Munakkad besides those of $C$. morus. As the egg mass could not be referred to the adult with certainty it is described here as Cerithium sp.

The spawn masses were observed in January-July period. The eggs are laid in a long string which as in C. morus is folded upon itself closely and compactly and forms a ribbon. The width of the egg string is 0.133 $0.200 \mathrm{~mm}$. and that of the ribbon $0.835-1.00 \mathrm{~mm}$. The ribbon, in its turn, may be thrown into loose or compact folds. Occasionally they are wavy or in a straight line. The spawn mass is covered by a slimy gelatinous matrix which is whitish or pale yellow in colour. Each egg is spherical, measures $0.066-0.083 \mathrm{~mm}$. across, and is surrounded by an egg covering (capsule) 
which measures $0 \cdot 108 \mathrm{~mm}$. across. The capsules are transparent and may or may not touch one another.

It takes about 4 days for the eggs to hatch out as free swimming veligers. The entire ribbon appears to dissolve away at the time of hatching. The newly hatched veliger measures $0.150 \mathrm{~mm}$. across the shell which is unsculptured. The outer lip of the shell is slightly extended in the middle. The velum is bilobed, the lobes being of almost equal size. The eyes and tentacles are not yet developed. The foot is ciliated. The operculum is colourless and the otocysts are distinct. The liver is pale yellow.

The two-day old veliger shows further growth in the size of the larval shell which measures $0.167 \mathrm{~mm}$. across. The projection in the middle of the outer lip is more pronounced. The tentacles and eyes are now developed and are clearly seen. The velum begins to show a sub-velum lined with small culia. The retractor is visible. The veliger thrived at the laboratory for about 4 days. During that period no further changes were noticeable in the larva. However the well-developed velum comparing to the size of the larva points to a long pelagic period in its life-history.

\section{Ianthinida}

The egg cases of Ianthina have been described by several authors outside India (Lamy, 1928; Laursen, 1953; Wilson and Wilson, 1956). Hornell (1921), Crichton (1941) and Gravely (1942) have made brief references to the egg cases of the same genus from India.

Ianthina prolongata Blainville (Photos $7 \& 8$ and Figs. 23 \& 24).-Brief references have been made to the egg cases of this species by Crichton, Gravely and Laursen (l.c.).

In the month of July and August, the period of strong winds which begin prior to the outbreak of south-west monsoon accompanied by rough seas, large number of floats of Ianthina with the egg cases attached underneath were collected along the shores of Gulf of Mannar near Vedalai. But during this period, in the present observation, floats were not found attached to the foot of the adult animals even though animals together with floats were reported. There appears to be only two species of Ianthina in Pamban area. They are $I$. janthina and $I$. prolongata. As the former appears to be viviparous, I am inclined to refer the present egg cases to the latter species.

Three floats with capsules in tact showed 110, 121 and 129 capsules respectively. Each capsule is a flattened, compressed pouch and is pale mauve in colour. In the preserved specimens (preserved in $5 \%$ formalin) the capsules become more or less colourless. The surface of the capsules is not 
smooth but wrinkled appreciably. The sides of the capsule are in many cases wavy. The distal end of the capsule is prominently but promiscuously jagged. The jags appear in certain places, to be arranged in 6-9 rows. The sides are also jagged in some capsules but less prominently. The capsules are not of uniform shape but generally pyriform or oblong pyriform.

The capsules are suspended from underneath the float. Each capsule is provided with a brownish-white stalk $(0.6-0.9 \mathrm{~mm}$. long and $0.116 \mathrm{~mm}$. wide), which is slightly twisted at the base. The length and breadth of the capsule vary from $4-6 \mathrm{~mm}$. and $1-3 \mathrm{~mm}$. respectively. The number of eggs per capsule ranges from $1,137-2,250$. On an average each egg mass contains 220,000 eggs.

The eggs appear to be suspended in a white nutritive fluid. Each egg measures about $0.066 \mathrm{~mm}$. The egg capsules kept at the laboratory on $21 \mathrm{st}$ August 1954 liberated the veligers on 23rd August 1954. At the time of hatching the entire top of the capsule slits open. Unfortunately the newly hatched veligers were attacked by the ciliates and were disturbed to a great extent. However, some of the less affected larvæ reveal the following details. The surface of the larval shell is rough and uneven when observed under high power. It measures $0 \cdot 083-0 \cdot 100 \mathrm{~mm}$. across. The velum is more or less in the form of a sheet without any lobes. It is colourless and bordered with small cilia. Eyes and tentacles could not be seen. Foot and operculum are present but otocysts invisible. The internal organs are not clearly distinguishable except for the liver. The larvæ at this or later stage of development could not be traced in the plankton samples collected from the Gulf of Mannar.

\section{Naticida}

The characteristic egg mass of this family is well known for a considerable number of species from other parts of the world (Lamy, 1928; Ankel, 1930; Melville, 1930; Hertling, 1932; Thorson, 1935, 1940, 1946; Lebour, 1937, 1945; Knudsen, 1950; Giglioli, 1955). Very little is known about the breeding habits of Natica from India except for brief references by Hornell (1921), Panikkar and Aiyar (1939), Gravely (1942) and Satyamurti (1952).

Natica marochiensis Gmelin (Photo 9 and Figs. 25-30).-This is the commonest species of Natica collected from the Pamban area. Large numbers of live spcimens have been collected from Kundugal Point in certain areas on the mud flat.

Besides Gravely and Satyamurti who have made brief references to the egg ribbons of this species from Madras and Kundugal Point respectively, 
the egg ribbon of this species has also been recorded from West Africa by Knudsen (l.c.).

The mud flats at Kundugal Point have been strewn with enormous numbers of egg ribbons of this species. The adult gastropods are not so commonly seen as their egg ribbons. The egg ribbons were also observed at Vedalai but no adults could be found in that area. Some of the adults of the present species were kept in the glass troughs with sandy bottom of $1 \frac{1}{2}-2^{\prime \prime}$ depth. They laid the egg ribbons in the month of January, temperature and salinity being $25 \cdot 2^{\circ} \mathrm{C}$. and $27 \cdot 12 \%$ respectively. The egg masses were observed in the field in the months of January, February, March, April, May, July, August, September, November and December. The breeding appears to take place all the year round.

The egg ribbons are in the form of an open ring, sometimes thrown into a spiral of $1 \frac{1}{2}-2$ rounds. They are encrusted with sand particles. They are usually greyish in colour. These sand agglutinated egg ribbons form fine substrata for Cerithidea fluviatilis which lay their gelatinous spawn masses not infrequently on their inner or outer surfaces. Eight egg ribbons taken at random for examination measure $3 \cdot 5-5 \cdot 0 \mathrm{~cm}$. across. They are about $81-190 \mathrm{~mm}$. long (measured along the periphery), $10-13 \mathrm{~mm}$. broad and $0.45-0.52 \mathrm{~mm}$. thick. The egg ribbon of the West African species is about $117 \mathrm{~mm}$. in length (measured along the periphery) and the innermost half of the egg ribbon is protruded as a broad collar giving the egg mass a somewhat conical shape. In the Indian species the 'collar' of the ribbon is not distinguishable. The inner margin of the egg ribbon is even and regular. So is the periphery though it is sometimes undulated or thrown into minute folds. The average number of egg spaces per row as seen in the vertical trans-section (i.e., internal view of the egg structure as seen in the cross-section by flattening the egg ribbon and cutting across its width) is 24 and there are about 122 such rows lengthwise (i.e., the length of the egg ribbon when it is uncoiled and flattened out on a plane surface). The egg spaces are absent along the periphery and inner margin. Roughly there are about 2,900 egg spaces per egg ribbon, each egg space measuring $0 \cdot 183-$ $0.367 \mathrm{~mm}$. across. It contains $3-7$ eggs. Each egg is surrounded by a thin and transparent egg capsule (egg covering). The egg and egg covering measure across $0.066-0.083 \mathrm{~mm}$. and $0.133 \mathrm{~mm}$. respectively. Knudsen's account does not contain any of these details except that there are 20-25 embroys per egg space, a number much larger than in the present species. The egg ribbon laid at the laboratory did not show further development. The egg ribbons collected from the field showed advanced stages of development. 
Among the species of Natica pelagic development seems to be the normal feature. But in Natica catena both pelagic (Lebour, 1937) as well as nonpelagic (Thorson, 1946) development have been observed. Thorson (1935) observed purely non-pelagic development in three species of Natica from East Greenland and Knudsen (1950) in a single species from West Africa. Ankel (1930) observes nurse egg feeding in $N$. catena. In the present species, however, the development is pelagic and no nurse-egg feeding has been observed.

As soon as the larvæ are ready to hatch out the egg ribbon made up of agglutinated sand particles dissolves into a mass of loose sand grains. In the meanwhile the egg coverings surrounding the embryos give way, probably by dissolution, so that the larvæ can now lead a pelagic life. The veliger in the first few hours after hatching is very active. It measures $0 \cdot 100-0 \cdot 116 \mathrm{~mm}$. across the shell. It is pale yellowish in colour. The velum is colourless and bilobed. The larval shell presents an uneven and rough surface. The foot and operculum are present, the former colourless and ciliated. The otocysts are fairly clearly seen as also the retractor. The eyes are black but the tentacles are not clearly visible. The alimentary tract as well as the liver are pale yellow.

The newly hatched veliger of this species could not be compared to that of the West African species because no details of veliger are given in the latter form except that the larva has a pelagic stage and the larval shell measures $100 \mu$ across the shell. The veligers thrived at the laboratory for 4-5 days during which time they did not grow or metamorphose.

Natica tigrina (Röding) (Photo 10 and Figs. 31-35).-There is no previous record of the breeding habits of this species.

Egg ribbons bigger in size on an average than those of $N$. marochiensis were also met with in Kundugal Point area. No other adult specimens except $N$. marochiensis could be observed along with them. However in one of the collection trips two live specimens of $N$. tigrina and one Polynices mamilla were observed in the same area. The apices of the shells of these two species were examined. It is found that the larval shell of the veliger hatched out from the egg ribbon agreed with the apex of $N$. tigrina in the measurement of the 1st whorl. Hence it is possible that these egg ribbons belong to N. tigrina.

The egg ribbons were observed in the field in the month of January, February, March, May, July, August, September and December. It is likely that the breeding in this species takes place all the year round as in N. marochiensis. 
The egg ribbons are in the form of an open ring but sometimes they are thrown into a spiral of $1 \frac{1}{2}$ rounds. They are greyish in colour with blackish tinge. A few egg ribbons, taken at random, measure $5 \cdot 6-7 \cdot 9 \mathrm{~cm}$. across. They are about $165-192 \mathrm{~mm}$. long (measured along the periphery), 23-28 mm. broad and $0 \cdot 80-1 \cdot 10 \mathrm{~mm}$. thick. The inner margin of the egg ribbon is shaped into a 'collar' which is more pronounced than in the previous species. This part of the egg ribbon is smooth and even but the periphery may be smooth or thrown into a series of characteristic folds. The spawn masses of C. fluviatilis are quite commonly found attached to the egg ribbons.

A transverse section of the egg ribbon shows about 110 egg spaces arranged distinctly in two planes (i.e., about 55 egg spaces per plane) which are placed one above the other. Section of the ribbon lengthwise reveals that there are on an average 500 such rows arranged in two planes, each plane containing half the number. Roughly there are about 40-55 thousand egg spaces in an egg ribbon. The egg space measures $0 \cdot 251-0.284 \mathrm{~mm}$. across. Each egg space contains only one embryo unlike the previous species. Each egg or embryo is surrounded by an egg covering (capsule) which is transparent, colourless and flexible. Some of the egg ribbons revealed in the section the larvæ without the egg coverings. The latter were probably dissolved and the larvæ are now ready to lead a pelagic life. This is probably the stage when the egg ribbon disintegrates for the capsule-free larvæ to come out.

A ribbon collected on 8xh August 1952 liberated the veligers on 13th August 1952. The embryo in the hatching stage shows thick and pinkish brown embryonic shell. The latter has very characteristic wavy spiral ribs as that of 'Natica sp. A.' from Iran figured and described by Thorson (1940). The embryo shows bilobed velum. Eyes, otocysts, foot and operculum are seen. The newly hatched veliger measui es $0 \cdot 200-0 \cdot 250 \mathrm{~mm}$. across the shell. The velum is well developed and has olive green pigment patches, two on each lobe. There is a sub-velum with minute cilia. The foot, operculum and otocysts are distinct. The foot is colourless and possesses a long contractile tentacle projecting at the distal end which is fully outstretched when the veliger swims. This feature is very identical with those of Natica canrena from Bermuda (Lebour, 1945). The operculum is white, thin and transparent. The eyes are present but only the right tentacle is developed at the time of hatching and the left one is not yet developed. The internal organs of the veliger are not distinctly seen through the sufficiently thick shell except for the heart-beat. The larvæ at this stage of development are commonly seen in the plankton samples from the Gulf of Mannar. 



32
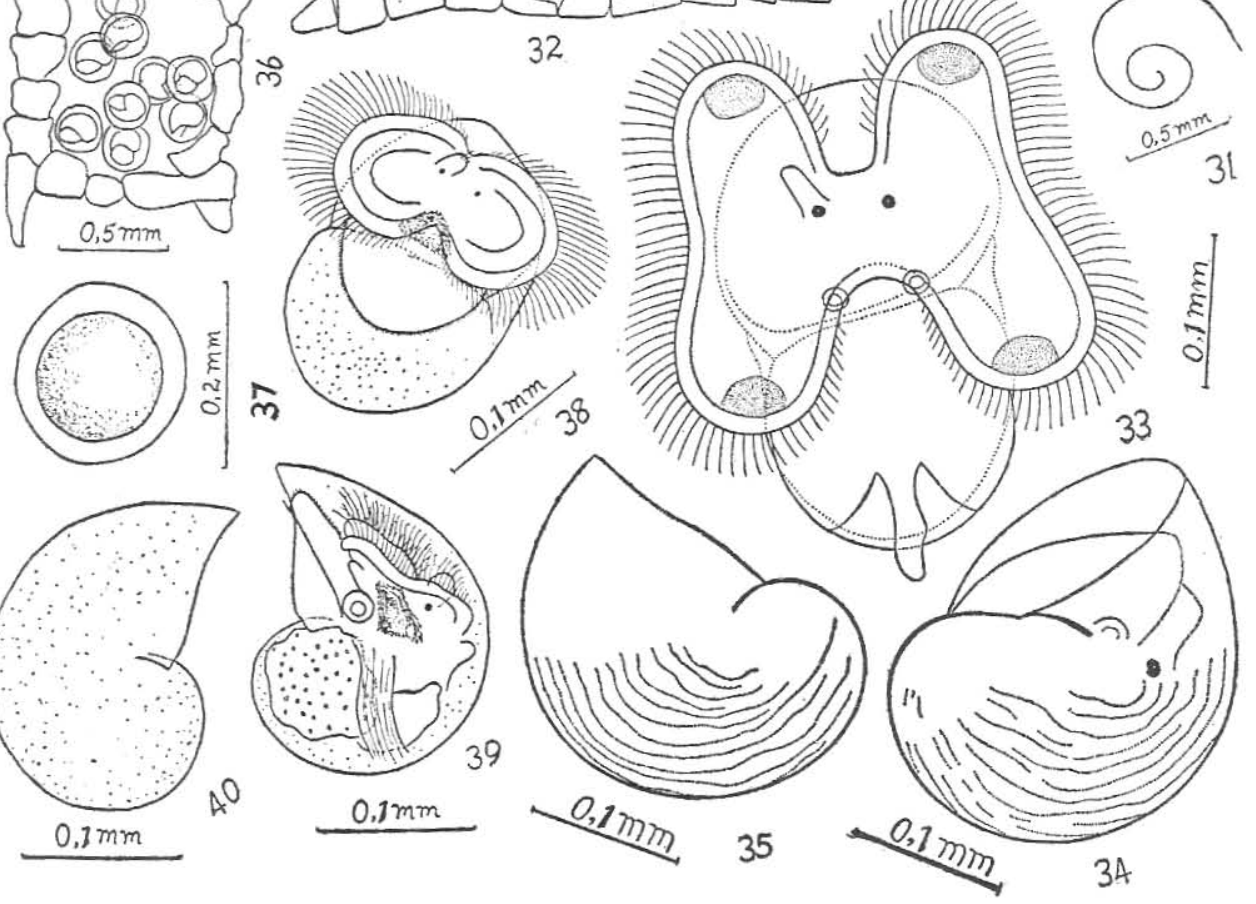

FIGS. $19-40$ 
Natica sp. A. (Photo 11 and Figs. 36-40).-Egg masses belonging to Natica were collected from Shingle Island on 22nd February 1956. They were found on sandy areas. But no adults of Natica could be observed in the area wherein the egg masses were collected.

The greyish egg ribbon is encrusted with sand particles and is thrown into $1-1 \frac{1}{2}$ spiral. The length in a few egg ribbons examined is about $39 \cdot 5 \mathrm{~cm}$. along the outer margin and $18 \cdot 2 \mathrm{~cm}$. along the inner margin. The ribbon is $3 \cdot 8-4 \cdot 5 \mathrm{~cm}$. in width and $0 \cdot 84-1 \cdot 29 \mathrm{~mm}$. in thickness. The egg spaces are arranged in one plane. The largest diameter of the egg space is $0.50-0.84 \mathrm{~mm}$. Each egg space contains a few eggs. The egg (preserved) measures $0.116 \mathrm{~mm}$. It 1 surrounded by a thin-walled, flexible and transparent capsule which measures $0 \cdot 167-0 \cdot 217 \mathrm{~mm}$. across.

The egg ribbon collected on 22nd February 1956 liberated the veligers 7 days hence. The newly hatched veliger measures $0.200 \mathrm{~mm}$. across. The larval shell which shows one whorl is slightly brownish and has dotted surface. The velum is colourless and bilobed. Eyes are black. Only right tentacle is seen. It shows a few hairs at the tip. Foot is ciliated. Operculum and otocysts are present. The region around the mouth is purplish. Liver is yellow. The animal is yellowish. The larvæ thrived at the laboratory for two days but showed no changes during the time.

Natica sp. B. (Figs. 41 \& 42).-Two egg masses having the features of Natica type were dredged near Kundugal Point in the month of January. The egg masses liberated the veligers even before reaching the laboratory. Therefore no details of the egg mass could be given except that the ribbon is fairly of large size and is light black in colour.

The newly hatched veliger measures about $0 \cdot 634-0 \cdot 651 \mathrm{~mm}$. across the shell which has one whorl and begins to show some spiral striations. The embryonic shell is unsculptured. The velum is colourless and has a tendency to four lobes. It measures $0.75 \mathrm{~mm}$. across in the middle. Each lobe measures about $1.10 \mathrm{~mm}$. lengthwise. Sub-velum is present. Eyes, tentacles and otocysts are present. Foot is yellowish and well developed. The alimentary tract, particularly stomach, is purplish. The veligers did not thrive at the laboratory for more than 2 days.

\section{Cyprceida}

The egg masses of Cypraca were described by several authors outside India ( $c f$. Lo Bianco, 1899; Vayssiere, 1923, 1927; Ostergaard, 1950). Ray (1951) gives an account of the systematics, habits, habitats, etc., of cowries. But their breeding habits have not been described from India. 
Erronea errones (Linné) (Photos 12 \& 13 and Figs. 43-49).--An account of the breeding habits of this species was given by the present author (Natarajan, 1954). More details are given here. This species is quite common in the Palk Bay waters living in the reef and rocky areas between Munakkad and Mandapam. They appear to be limited to shallow waters as is usual with cowries.

The cowries were found perching over the egg masses which are laid on the undersurface or crevices of stones and boulders. The egg mass is thus hidden from view but the rather bulged foot and the completely immobile state of the animal suggest very clearly that the animal is brood-caring. The immobile animal appears to be in a state of tension as is seen from the expanded foot covering the egg mass, the extended mantle lobes covering the entire shell and the protruding siphon; when the animal is removed it becomes very uneasy and moves about the glass trough restlessly.

The breeding of this species was observed in the month of September (temperature $27 \cdot 8^{\circ} \mathrm{C}$., salinity $37 \cdot 71 \%$ ), October (temperature $28 \cdot 0^{\circ} \mathrm{C}$, salinity $36 \cdot 76 \%$ ), November (temperature $28 \cdot 0^{\circ} \mathrm{C}$., salinity $36 \cdot 58 \%$ ), December (temperature $26 \cdot 0^{\circ} \mathrm{C}$., salinity $27 \cdot 59 \%$ ), January (temperature $25 \cdot 4^{\circ} \mathrm{C}$, salinity $27 \cdot 09 \%$ ), February (temperature $25 \cdot 0^{\circ} \mathrm{C}$., salinity $27 \cdot 45 \%$ ) and March (temperature $24 \cdot 4^{\circ} \mathrm{C}$., salinity $28 \cdot 33 \%$ ).

The egg mass is nearly circular about $23-26 \mathrm{~mm}$. across, and $8-10 \mathrm{~mm}$. in thickness at the centre. In the fresh condition it is yellowish in colour. It turns gradually pinkish brown and ultimately dull purple with the development of the larvæ. Five egg masses examined contained 481, 501, 507, 515 and 546 capsules respectively. The number of eggs per capsule ranges 20-76. All of them develop into embryos. It was observed that the capsules in the present egg mass are deposited in 5-6 layers superimposed upon one another, the diameter of the layer being largest at the base and showing gradual decrease towards the top. The pale yellow capsules are transparent and show variations in size and shape. They measure each $1 \cdot 45-3 \cdot 25 \mathrm{~mm}$. long and $1.40-1.80 \mathrm{~mm}$. broad. No preformed exit passage is present. The capsule is usually broad at the top and narrows down towards one side. It extends into a basal plate for attachment. The largest diameter of the base ranges $0 \cdot 50-0.85 \mathrm{~mm}$. In sections of the egg mass the mode of attachment of the capsule is clearly seen. The first layer is attached to the substratum. The capsules of the second layer attach themselves by their bases to the distal end or near about the distal area of the capsules of the first layer. The same arrangement is repeated by the third layer on the second and so on. The capsules are also glued sideways which give a compactness to the egg mass. 
The eggs are yellowish (or yellowish-brown) in colour, and measure each about $0.263-0.267 \mathrm{~mm}$. The newly hatched veliger measures $0.373 \mathrm{~mm}$. across the shell. The latter is pale brownish in colour with reticulate markings on it. The velum is bilobed and colourless. There is a distinct subvelum with short cilia. The eyes are distinct but only the right tentacle is present and the left one is not yet developed. The statocysts are present. The foot is well developed, ciliated and shows diffuse black colouration. The operculum is colourless. While swimming the larva is either partly or fully surrounded by the mantle. The mouth, œsophagus, stomach and intestine are dark purplish in colour and are distinctly seen through the shell. The heart-beat is clearly visible. The liver is yellowish and appears pressed against the stomach. The larvæ thrived at the laboratory for about a week but no changes could be noted. The larvæ at this stage of development are very often seen in plankton samples from Palk Bay.

\section{Tonnida (Doliider)}

The egg masses of various species of Tonna (Dolium) were described in the literature (Thorson, 1940; Knudsen, 1950; Ostergaard, 1950). Panikkar and Tampi (1949) described a doliid egg mass from Krusadai area.

Tonna dolium (Linné) (Photos 14 \& 15 and Figs. 50-54).-Egg masses belonging to Tonna were collected from Vedalai, Mandapam, Krusadai and Shingle Islands. Live specimens and shells of Tonna dolium have been observed in Shingle Island. The larval shell of veliger hatched out from the egg ribbon agreed with the apex of an young one of $T$. dolium in the measurements of 1st whorl. Thus it is likely that the egg ribbon belongs to the same species. This also confirms the identification of Dr. Thorson (l.c.) of a similar ribbon in Iran referred with doubt to Dolium maculatum ( $T$. dolium).

The egg ribbons were observed in February, April and October. Usually the ribbons were found in broken pieces. This is particularly so in ribbons at advanced stages of development. Two of the ribbons (one of them bigger than the other) however are more or less complete. The dimensions as well as other features of the bigger ribbon are: length of the ribbon $36 \mathrm{~cm}$.; breadth $8.4-9.5 \mathrm{~cm}$; thickness $1.71-1.87 \mathrm{~mm}$.; number of egg spaces per row $38-41$ (at the ends 20-25); total number of rows 125 ; largest diameter of the egg space $3.03 \mathrm{~mm}$; l largest diameter of the exit hole $0.72 \mathrm{~mm}$.; number of eggs per egg space $9^{2}-101$. The details of the smaller ribbon are: length of the ribbon $22.5 \mathrm{~cm}$; breadth $4 \cdot 1-5 \cdot 7 \mathrm{~cm}$. (at the end $2 \cdot 9-3 \cdot 7 \mathrm{~cm}$.); thickness $1.21 \mathrm{~mm}$; number of egg spaces per row $31-35$ (at the end 11-26); total number of rows 123; largest diameter of the egg space $2.09 \mathrm{~mm}$.; largest diameter of the exit hole $0.880 \mathrm{~mm}$. Number of 
eggs per egg space 29-32. The smaller ribbon is probably laid by an young one.

The egg mass is in the form of a gelatinous band. It is brownish in colour. The egg spaces are arranged in curved rows, and have each a flat bottom and convex top. They may have four or five sides or be circular or oval in outline. The exit hole may be elliptical or circular. The capsule itself is colourless and transparent.

The egg is spherical and brownish and measures $0 \cdot 217-0 \cdot 234 \mathrm{~mm}$. across. The eggs are arranged in a semi-lunar mass in freshly laid egg ribbons. They are surrounded by white nutritive substance which the embryos utilise during the development. Roughly it takes about 15-17 days from egg to the time of hatching.

The newly hatched veliger measures $0.418 \mathrm{~mm}$. across the shell which has one whorl and is brownish. The surface of the whorl is uneven and shows reticulate sculpture. The colourless velum is bilobed with a tendency to four lobes and measures $0.417 \mathrm{~mm}$. across. Each velar lobe measures $0 \cdot 367-0.468 \mathrm{~mm}$. in length and $0 \cdot 150-0.167 \mathrm{~mm}$. in width. Sub-velum bordered with small cilia is present. Eyes are black. Only the right tentacle is seen with fine hairs at the tip. The foot has a ciliated tentacular process at the distal end. Ciliated proboscis is seen. The otocysts are distinct. The operculum appears to consist of two pieces, the outer one slightly jutting out. The liver is yellow.

The present observation is in agreement, in a general way, with that described for Iranian species by Thorson (l.c.). Besides normal development (i.e., all the eggs develop into embryos), Thorson also observed in a few egg spaces each having a large embryo measuring about $2 \mathrm{~mm}$. He was not quite sure whether this monstrous growth was due to real nurse egg feeding or 'cannibalism'. However such monstrous embryos were not found in the Indian species.

The doliid egg mass described by Panikkar and Tampi (l.r.) from Krusadai area also seems to belong to $T$. dolium only.

Tonna sp. (Photos 16-18 and Figs. 55-59).-Egg ribbons belonging to Tonna have been collected from Krusadai, Shingle Island, Vedalai and Mandapam. But they could not be referred to the adults with certainty.

The egg masses were observed in the month of January (temperature $24 \cdot 5^{\circ} \mathrm{C}$., salinity $27 \cdot 23 \%$ ), May (temperature $30 \cdot 5^{\circ} \mathrm{C}$, salinity $33 \cdot 75 \%$ ), July (temperature $20.0^{\circ} \mathrm{C}$., salinity $33.69 \%$ ) and November (temperature $27 \cdot 0^{\circ} \mathrm{C}$., salinity $36 \cdot 42 \%$ ). 



$4^{5}$
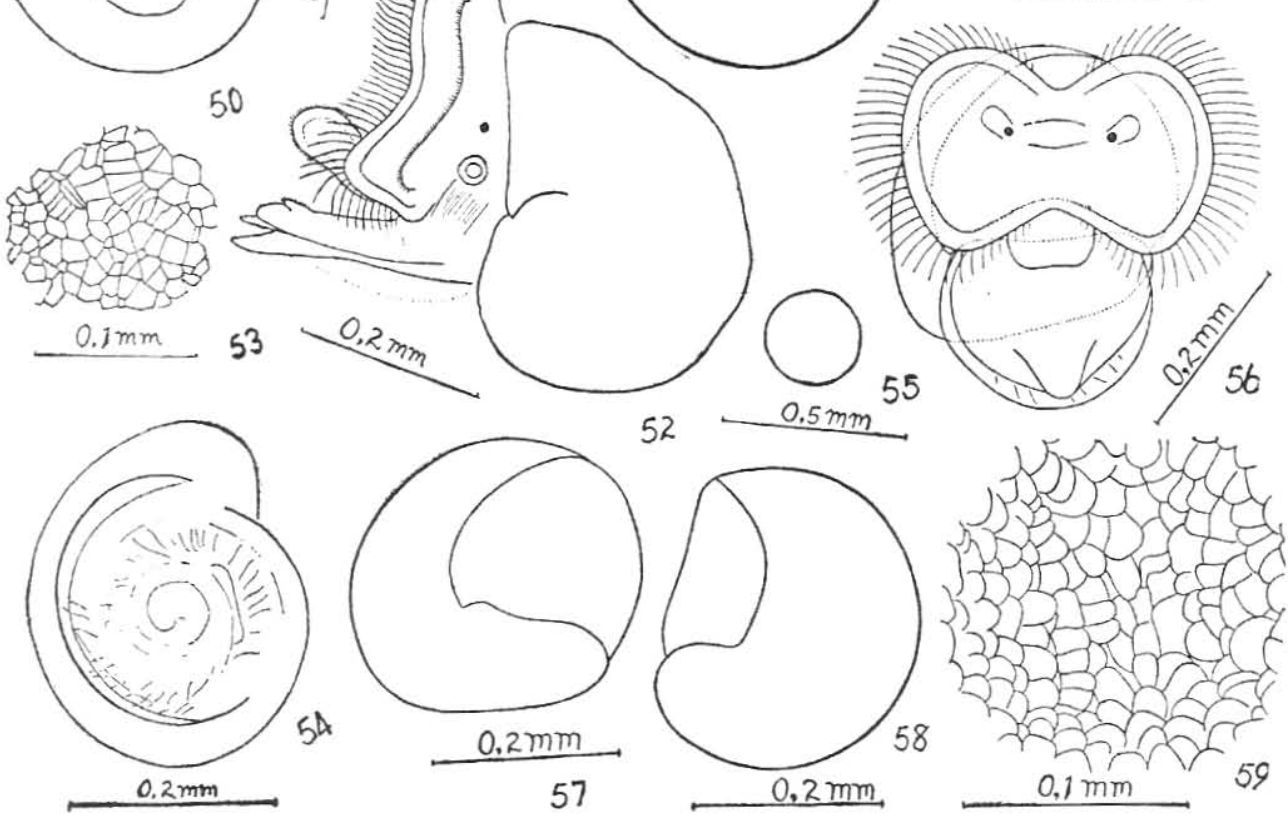

FIGs. 41-59 
The egg mass is a gelatinous band or ribbon. It is brownish or pinkish yellow, but colourless in the spent up condition. They are usually washed ashore and never attached to any substratum.

The ribbons measure about $292 \mathrm{~mm}$. long, 54-80 mm. broad and 1.6$1.9 \mathrm{~mm}$. thick. The egg space (capsule) may be 4,5 or 6 sided or circular or oval. Its largest diameter is $2-2.65 \mathrm{~mm}$. The wall of the egg space is smooth and transparent and has on the convex face a preformed exit hole which is very vague or unpronounced in the freshly laid ribbon, but becomes clearer at the time of hatching of the larvæ. It is circular, elliptical or oblong in shape, having largest diameter of $0.88-1.00 \mathrm{~mm}$. The exit hole is covered by a thin membrane which gives way at the time of hatching. About 31-38 (and 12-13 at the ends) egg spaces are arranged side by side in curved rows. There are about 117 such rows and 3,300 capsules in a ribbon. The number of eggs in an egg space ranges between 95 and 110. All the eggs seem to develop into embryos. Roughly about 336,000 embryos emerge out of a single ribbon.

The eggs are yellowish or brownish yellow and measure each $0.233 \mathrm{~mm}$. across (based on preserved material). The freshly laid ribbons in which the eggs are grouped in a semi-lunar mass in each capsule, take about 17 days to hatch out. The eggs are surrounded by a white thick sheet of nutritive fluid.

The yellowish embryos emerge out as large veligers through the exit hole. They measure each $0 \cdot 317-0 \cdot 334 \mathrm{~mm}$. across the shell, which shows about a whorl, is pale yellowish and presents a characteristic reticulate sculpture. The velum is colourless and has more or less two equal lobes. Eyes and tentacles are seen. Foot and operculum are present. The otocysts are present but quite small and indistinct. The veligers thrived at the laboratory for two days.

\section{Muricida}

The egg masses of some species of Muricidæ are known in the literature (Annandale and Kemp, 1916; Hornell, 1921 ; Lamy, 1928; Burkenroad, 1931; Risbec, 1932, 1935; Fischer and Raffy, 1933; Mohr, 1933; Lebour, 1937, 1945; Thorson, 1940; Gravely, 1942; Knudsen, 1950; Ostergaard, 1950; and Chari, 1950). The egg cases common at Tuticorin and referred to Murex by Horneli (1921) appear to belong to Thais.

Murex virgineus var. ponderosa Sowerby (Photo 19 and Figs. 60-69).The breeding habits of this species are described here for the first time. 
Satyamurti (1952) has recorded this species from Kundugal Point and Pamban. It has also been collected in large numbers at Seeniyappa Dharuga and Vedalai regions.

An adult specimen of this species measuring $6 \cdot 5 \mathrm{~cm}$. in length and $4.4 \mathrm{~cm}$. in breadth laid an egg mass on 8th December 1954 on the glass of the aquarium close to the surface of the water, the temperature and salinity being $24 \cdot 2^{\circ} \mathrm{C}$. and $29 \cdot 25 \%$ respectively. It took about $42 \frac{1}{2}$ hours to complete the spawning process which resulted 61 capsules being laid. The adult was transferred to a glass trough and removed to the laboratory for observation. The same specimen laid one more capsule on the bottom of the glass trough after $5 \frac{1}{2}$ hours; another specimen of a length of $7 \cdot 3 \mathrm{~cm}$. and largest breadth of $4.6 \mathrm{~cm}$. laid an egg mass consisting of 94 capsules and took about $39 \frac{1}{2}$ hours; a third one of a length and breadth of $6.7 \mathrm{~cm}$. and $3.9 \mathrm{~cm}$. respectively laid 91 capsules in about $34 \frac{1}{2}$ hours. In the second and third cases the salinity and temperature were more or less the same as the first one.

The breeding in this species was observed in November, December, January, February, March, May, June and July. It is likely that the breeding in this species is all the year round.

The pale yellow capsules are broad at the top and become narrower towards the base. They are slightly flattened bounded by two strong longitudinal ridges, one on each side. On one face there is a groove in the middle which is broad and much pronounced at the top and becomes narrower and shallower towards the base; in some the groove is indistinct beyond the middle of the capsule. The other face is smooth. The length and the largest breadth of the capsule are $9 \cdot 5-11 \mathrm{~mm}$. and $4 \cdot 6 \mathrm{~mm}$. respectively. The capsule presents an elliptical outline in cross-section. Its top, viewed from above, is kidney-shaped and has an edge which curves upwards. In the centre there is a circular or elliptical exit hole which measures $1.3-1.4 \mathrm{~mm}$. and is covered by a thin, transparent membrane. Each capsule has a well-developed basal plate and the bases are confluent so that there appears to be a broad sheet from which these capsules stand vertically.

The eggs which are white and measure each $0 \cdot 200-0.217 \mathrm{~mm}$. across, are suspended a11 over inside the capsule in a gelatinous, colourless, thick fluid. The number of eggs per capsule ranges 440-731. Of these only a few develop into large embryos while the rest form nurse eggs. The newly laid capsules show embryos in the hatching stage in about 20 days. At the time of hatching the number of embryos per capsule ranges 9-30.

The covering membrane of the exit hole gives way at the time of hatching. The embryos at the hatching stage show remarkable variations in size ranging 
$0 \cdot 54-1.83 \mathrm{~mm}$. But about $75 \%$ of them fall within $1 \cdot 18-1 \cdot 75 \mathrm{~mm}$. range. It is not possible, at the moment, to attribute any specific causes but it is likely that this variation may be due to the disparity in the consumption of nurse eggs by the embroys, i.e., there may be some sort of competition among the embryos in the consumption of nurse eggs.

The embryo examined at an early stage has hardly one whorl. Velum is bilobed and is bordered with small cilia. Eyes are small and the tentacles not yet developed. Foot is present but the otocysts are not clear. The embryo itself is little differentiated and apparently only contained a yolky mass. Heart-beat is visible.

At the next stage the embryo has a shell of about two whorls the second whorl showing granulated surface. It has a shell-siphon. The velum shows a tendency to four lobes. The opercular structure of the foot is now seen. The tentacles are now developed. The embryo is still little differentiated. The embryo about to hatch out has a shell of $2 \frac{1}{2}$ whorls, showing a welldeveloped shell-siphon. The velum is distinctly four-lobed, each lobe being narrow and long. The larva partly crawls and partly swims, a feature denoting short pelagic period. The embryos did not hatch out in the laboratory condition. It is very likely that they emerge out of the capsule at this stage as free swimming veligers.

After 2 days the veliger (measuring about $1.78 \mathrm{~mm}$. in the present case) begins to lose the velum. The velum is reduced into two lobes, the right lobe is smaller than the left and about to disappear. In about $2 \frac{1}{2}$ days the velum is completely lost and the young ones, in the present case, measure each about $1.85 \mathrm{~mm}$. The foot is well developed and the young ones crawl about. The operculum is brownish. The eyes and tentacles are very well developed. The young ones thrived at the laboratory for about 20 days. They have now $2 \frac{3}{4}-3$ whorls and measure each $2.05 \mathrm{~mm}$. across the shell.

\section{REMARKS}

The nurse egg feeding, in this species, is worth mentioning. The embryos at early stages were dissected out from the egg capsules and kept in a watchglass along with nurse eggs. They reach the nurse eggs and each egg is manipulated towards the mouth with the help of the velar lobes and the foot. Then they press the egg with the velar lobes. The egg collapses due to pressure. Then the eggs are gradually sucked up which do not appear to take more than 2 minutes. This process of nurse egg feeding appears different from those of Nucella and Buccinum types (Thorson, 1946). 



Figs. $60-81$

Murex trapa Röding (Photo 20 and Figs. 70-78).-The adult specimens of this species have been collected in large numbers from Vedalai and Pudumadam areas. The present egg masses collected from Vedalai and Pudumaciam in November and December 1955 liberated the veligers whose larval 
shells begin to show the long anterior canal and processes thereby revealing their affinity to Murex trapa. The apex of an young one of Murex trapa also agreed broadly with the larval shell. The present egg masses are therefore referred with some certainty to this species.

The egg mass has a characteristic structure. It consists of a number of cone-like structures, more often appearing as though budding from a primary cone. Each cone-like structure is really formed of a number of small capsules which are strung in a regular pattern resulting in hollow cone with diamond-shaped cavities to the outside. These cavities communicate with the internal main or axial cavity of the cone. Individual capsules are united only externally by basal ends while the distal ends are free and compact opening to the axial space. There are as many as $24-36$ cone-like protuberances in an egg mass. Each of them consists of 107-167 capsules. On an average there are 4,110 egg capsules in an egg mass.

The capsule is a compressed pouch. It is fairly transparent showing the embryos inside. The length and the largest breadth of the capsule are $5 \cdot 0-7 \cdot 5 \mathrm{~mm}$. and $2 \cdot 5-3 \cdot 75 \mathrm{~mm}$. tespectively. The top of the capsule forms the exit hole for the emerging larvæ. It is circular or elliptical and is covered by a thin membrane. The largest diameter of the exit hole is $1 \cdot 32-1 \cdot 49 \mathrm{~mm}$. The lacuna of the pouch is $0.94-1.76 \mathrm{~mm}$. Each capsule has a base but no stalk or peduncle.

The number of eggs in a capsule ranges 163-204. They are suspended in a mucous-like fluid. They are spherical and yellowish and measure each $0.267 \mathrm{~mm}$. It takes about 20 days from the time the eggs are laid to the time of hatching. In this species all the eggs do not develop into embryos. Only 10-26 embryos appear to develop, in each capsule the rest of the eggs subserving as nurse eggs. In this case, therefore, the embryos attain a large size before emerging out by feeding on nurse eggs and surrounding fluid. The embryos did not hatch out in the laboratory condition. However they were dissected out from the capsules and kept in finger bowls. The velum of the larva is four-lobed. Sub-velum is present with small cilia. The width of the velar lobe is about $0.334 \mathrm{~mm}$. The eyes are black. The tentacles are fairly prominent. The foot is well developed with blackish tinge. The operculum is present. The otocysts are not clear. The liver is yellowish. The larval shell measures $1 \cdot 00-1 \cdot 27 \mathrm{~mm}$. It has $2 \frac{1}{3}$ whorls and is pale brown. The last whorl shows angulation in the middle as well as transpiral striations. The outer lip of shell is extended forward in the middle. The larva settled down in about $2 \frac{1}{2}$ days losing velar lobes. The young one examined after two days shows the shell of $1.70 \mathrm{~mm}$. in length. The anterior canal of the 
shell is more elongate. The outer lip of the shell begins to show processes and transpiral ridges. The foot is well developed. The eyes are small. The tentacles are long and slender. The young one thrived for about 12 days at the laboratory. The 12-day old young one shows further growth and has a shell of $1.85 \mathrm{~mm}$. in length. Anterior canal shows further prolongation.

Thais bufo (Lamarck) (Photos 21 \& 22 and Figs. 79-81).-Egg clusters of Thais were collected from Vedalai and Mandapam. In these areas both T. rudolphi and T. bufo are well represented. A single young specimen of T. rudolphi showed the apex more or less intact. The apex was compared with the larval shell of the veliger hatched out from the egg cluster and was found larger in the measurement of 1 st whorl. Therefore it is very likely that the egg cluster belongs to the other species namely $T$. bufo. Direct comparison of the apex of $T$. bufo with the larval shell was not possible as the young ones of T. bufo with apex intact could not be collected. A brief account of the egg capsules of Thais bufo has been given by Gravely (1942) from Madras and Chari (1950) from Mandapam.

The breeding of this species was observed in January-June period. The egg clusters are glued generally underneath the jutting edges of rocks or in their crevices. They usually comprise of yellow, violet and grey capsules. The yellow capsules showed embryos in their early development and grey ones, embryos in the hatching stage. The violet capsules show a column of yolk probably due to the disintegration of egg or embryo. The clusters are generally laid close to each other and it is therefore difficult to ascertain the number of egg capsules laid by a single female.

The egg capsules are like small cylindrical tubes with long stalks and confluent bases. The distal end is slightly bulged. The top of the capsule bears an exit hole which may be circular or elliptical and is covered by a transparent membrane. The exit passage measures $0.55-0.60 \mathrm{~mm}$. across. The length (excluding the stalk) and largest breadth of the capsule are 5.00$7 \cdot 00 \mathrm{~mm}$. and $1 \cdot 50-2 \cdot 05 \mathrm{~mm}$. respectively. The stalk is slender, long and flattened and is $3-5 \cdot 5 \mathrm{~mm}$. long. Its largest and smallest breadth are $0 \cdot 450$ $0.728 \mathrm{~mm}$. and $0 \cdot 250-0 \cdot 450 \mathrm{~mm}$. respectively. The number of embryos per capsule is $254-353$.

The egg capsules contain a colourless fluid. They are almost packed with embryos at the time of hatching. The thin membrane covering the exit hole gives way at the time of hatching. It is interesting in this connection to note that the larvæ of Thais hippocastaneum never use the exit hole but come out through a hole in the side wall which they have rasped out themselves (Thorson, 1940). 
Among purpurids the development may be pelagic or non-pelagic (Lebour, 1937; Thorson, l.c.). Thais hamostoma provides a fine example of pelagic as well as non-pelagic development in the same species in different areas. It is pelagic in Lousiana ( $c f$. Burkenroad, 1931) and non-pelagic in West Indies (Korschelt and Heider, 1936). Nurse egg feeding has been noted in T. hippocastaneum. In the present species the development is pelagic and no nurse egg feeding has been observed.

Embryos examined at the time of hatching measure each 0.283$0.367 \mathrm{~mm}$. across the shell. Of these, larvæ of $0.334-0.367 \mathrm{~mm}$. size seem to be predominant. In certain capsules some of the embryos are far less developed measuring only $0.217 \mathrm{~mm}$. These embryos appear to form only a small negligible percentage.

The newly hatched veliger (measuring $0 \cdot 334-0 \cdot 367 \mathrm{~mm}$.) has a shell of just more than one whorl. The shell has beaten surface as is seen in $T$. carinifera. The velum is bilobed and colourless. There is a distinct sub-velum with small cilia. The eyes are black and distinct. Only the right tentacle appears well developed and the left one is just beginning to show up. This disparity of development in tentacles in newly hatched larvæ have been met with in many other species. There are few long hairs at the tip of right tentacle. The foot and operculum are present, the former is ciliated. The otocysts are distinct. The liver is yellow. The alimentary tract is of purple colour especially the stomach and the anal region. There is a dark purplish pigment spot in the region of anus. The veliger thrived at the laboratory for $2 \frac{1}{2}$ days, without showing any further change.

Thais tissoti (Petit) ( Photos $23 \& 24$ and Figs. 82-85). - There is no previous record of the reproductive habits of this species.

Six egg masses belonging to purpurid type were dredged on 13th December 1954 near Rameswaram Road at 4 fathoms. Thais tissoti and Drupa heptagonalis were the only forms that were collected in that area. The larval shell of the veliger, liberated from the egg mass, agreed broadly with the apex of Thais tissoti in the measurement of the 1st whorl. It is therefore likely that the egg masses belong to the same species. Satyamurti (1952) has recorded this species at Pamban.

The egg masses were attached to the brown algæ Spathoglossum asperum. They consist of $80,55,59,25,75$ and 62 capsules respectively. The largest diameter of the egg mass is $6-11 \mathrm{~mm}$. The capsules are laid at a distance of about $0.50 \mathrm{~mm}$. from each other. The cylindrical capsule is pale brown and has a smooth, colourless, transparent surface. It has no stalk unlike the preceding species and the well-developed basal plate of each capsule 




FIGs, $82-102$

merge completely with each other to form a common base. The distal end of the capsule has a smaller diameter $(0 \cdot 45-0.50 \mathrm{~mm}$.) than the rest of the capsule and has a flattened top which is provided with a thin membrane. Here there is no preformed exit hole but the entire top forms the exit passage 
for the emerging larvæ. The length and the largest breadth of the capsule are $1 \cdot 90-2 \cdot 50 \mathrm{~mm}$. and $0 \cdot 70-1 \cdot 90 \mathrm{~mm}$. respectively. The number of the embryos per capsule is 19-32. All the eggs develop into embryos.

The embryos about to hatch out occupy almost the entire capsule. The larval shell is thin and fragile and measures about $0.317 \mathrm{~mm}$. across. Its surface shows beaten appearance. The edge of the aperture is slightly brownish. The shell-siphon is beginning to appear. The animal is pale yellow. The velum is bilobed and shows brownish colouration on the border of velar lobes. Sub-velum is present but not distinct enough. The eyes are distinct. Only the right tentacle is present. The foot is ciliated. The operculum and otocysts are present. A violet spot is present near the area of anus. The liver is pale yellow.

The newly hatched veliger thrived at the laboratory for 2 days. The larval shell now measures $0.350 \mathrm{~mm}$. The rather small sized velum of the veliger point to short pelagic period.

Thais sp. A. (Photo 25 and Figs. 86-88).-No previous account is available of the egg mass of this species. Egg clusters attached to the blades of the seaweed Gracilaria corticata (Rhodophycex) were found entangled in the shore-seine operated in the Pudumadam areas. The smooth, unridged capsules are laid close to each other at a distance of $0.55-0.75 \mathrm{~mm}$. They are cylindrical and fairly transparent. The top of the capsule which forms the exit passage for the emerging larvæ is flat or slightly convex and provided with a thin membrane. The largest diameter of the exit passage is about $0.65 \mathrm{~mm}$. The basal plates of the capsules are confluent and forms a broad sheet. The unstalked capsule is slightly bent or curved. It is not uniform in width and is largest in the middle. The length and the largest breadth of the capsule are $3 \cdot 75-5 \cdot 50 \mathrm{~mm}$. and $0 \cdot 90-1 \cdot 15 \mathrm{~mm}$. respectively.

The newly laid egg clusters are quite yellowish due to the yellowish eggs. The eggs which were in the early stages of development measured $0.200 \mathrm{~mm}$. across. They were evenly distributed inside the capsule. All of them develop into embryos. The number of the embryos per capsule is 57-92.

It takes roughly 4-5 days for the egg to hatch out. The larvæ about to hatch out could be seen moving about actively inside the capsule. The larval shell measures $0.367 \mathrm{~mm}$. across and has beaten surface. The shellsiphon is slightly brownish. The larvæ are yellowish. The velum is bilobed. Sub-velum is present. Eyes are distinct. Only the right tentacle is present. It has few fine hairs at the tip. The foot and operculum are present, the former is ciliated and the latter is whitish in colour. The otocysts are prominent. The stomach and anal part of the alimentary tract are pale-pinkish. 
The tissue near the anal area is purple and the liver is yellow. Heart-beat is visible. The newly hatched veligers thrived at the laboratory for about three days.

Thais sp. B. (Photo 26 and Fig. 89).-The egg mass of this species was not described before. The egg clusters, attached to shells or seaweeds, were collected from Pudumadam in the month of December 1954. They are thick yellowish when freshly laid and fade into dull grey with the development of the larvæ. The capsule has no stalk and is bent on one side. It has a more or less uniform width excepting the apical area where it extends into a nipple-like structure. The capsule is pillar-shaped and recalls that of Thais carinifera figured and described by Thorson (1940) from Iran. The nipple is thin and transparent and breaks off at the base at the time of hatching and leaves an exit passage for the outgoing larvæ. The capsule is smooth and semi-transparent. The length and the largest breadth of the capsule are $8-10 \mathrm{~mm}$. and $1 \cdot 15-1 \cdot 30 \mathrm{~mm}$. respectively. The average number of eggs per capsule is 146 .

The eggs are yellow and are already in the early stages of development and measure each $0 \cdot 200-0 \cdot 250 \mathrm{~mm}$. across. It may take about 4 days for the eggs to hatch out as free swimming veligers. The newly hatched veliger measures $0.417 \mathrm{~mm}$. across the shell which shows the beaten appearance. Unfortunately the larvæ were preserved by mistake before making a detailed examination in the living condition. However, the following details may be given: The velum is colourless and bilobed. It is bordered with long cilia. The eyes, foot, operculum and otocysts are distinctly seen.

Thais sp. C. (Photo 27 and Figs. 90-92).-The egg masses collected from Shingle Island in the month of February 1955 have all the features of the egg cluster of Thais but could not be referred to the species with certainty. They were found attached to the crevices of the rocks and stones.

The egg clusters consist each of about $60-80$ capsules. The length and the largest breadth of the capsule are 3-4 mm. and 1.59-1.82 mm. respectively. The capsule is vase-shaped and opens at the distal end by a short neck covered by a thin membrane which gives way at the time of hatching. Viewed from above, the exit passage shows a more or less elliptical outline which has the largest diameter of about $0.935 \mathrm{~mm}$. There are about 354 392 embryos in each capsule.

The newly hatched veliger measures $0 \cdot 183-0.233 \mathrm{~mm}$. across the shell. But the larvæ measuring $0 \cdot 200-0 \cdot 217 \mathrm{~mm}$. appear to be predominant. The shell is brownish and shows one whorl. It has beaten surface. The velum 
is bilobed and shows brownish pigmentation along the margin. Sub-velum is present. It also shows a line of brownish pigmentation. Eyes are black. Only right tentacle is seen. It shows a few fine hairs at the tip. Foot has a characteristic shape and is ciliated. Besides a few fine hairs, there are a few dark pigment dots at the free end of the foot. Otocysts and operculum are present. Liver is yellow. Retractor is seen. The animal is yellow. The veliger thrived at the laboratory for 2 days.

\section{Pyrenidae (Columbellida)}

The egg capsules of various species of Pyrene (Columbella) have been described by previous workers (Petit and Risbec, 1929; Thorson, 1935, 1940 ; Franc, 1943; Knudsen, 1950; Amio, 1955). No details seem to be available regarding the breeding habits of any species of Pyrene from India.

Pyrene flavida (Lamarck) (Photos 28 and 29).-Live specimens of this species were observed in Pamban sticking to dead corals on the reefs. Adult specimens kept at the aquarium towards the end of August 1954 laid an egg mass on 20th September, the egg mass being attached to the glass of the aquarium very near the surface of the water. Temperature and salinity at the time of spawning were $27^{\circ} \mathrm{C}$. and $35.01 \%$ respectively.

The egg mass as a whole has a length of about $2 \cdot 1 \mathrm{~cm}$. and a largest width of $1 \cdot 2 \mathrm{~cm}$. It consists of 30 egg capsules. Each capsule has a very conspicuous basal disc with which it is attached to the substratum. The basal plates of all capsules tend to fuse or merge with each other.

The capsule looks helmet-shaped with its adhesion disc. It is a little pressed in the middle on one side. On the opposite side is seen a keel in some capsules and in others it is not clear or absent. There is no peduncle. The basal plate is round or longish oval. The largest diameter of the adhesion disc is $3-4 \mathrm{~mm}$. The length and breadth of the capsule are $1 \cdot 70$ $3 \cdot 15 \mathrm{~mm}$. and $2 \cdot 15-2 \cdot 75 \mathrm{~mm}$. respectively. The number of eggs per capsule is $3-24$.

The capsule which is pale brownish in colour is unsculptured and is fairly transparent so that eggs are visible through the wall. The wall of the capsule at the top is very thin and probably forms the exit passage for the larvæ at the time of hatching. Petit and Risbec (l.c.) described the egg capsules of the same species (C. flava) from New Caledonia. The New Caledonian species has more than semi-globular egg capsules with a keel at one side. It has no peduncle and is attached to the substratum by a basal disc. The columbellid egg capsules are of different types (Thorson, 1940). Thus in $C$. tring $a$ the capsule is cucurbiform and is attached to the substratum by a 
short stalk. In C. versicolor the capsule is more than semi-globular with one or two keels without stalk and possess a flattened area at the top of the capsule separated from the side walls by a faint keel. In $C$. blanda this keel has developed into a collar-like membrane and in C. rosacea two collar-like membranes are present on the outer surface of the capsule. In Pyrene misera (Amio, 1955) the capsule is dome-shaped with an adhesion disc. At the top there is an elliptical origin of exit hole between two indistinct keels.

Nurse egg feeding seems to be the common phenomenon in Columbellidæ and this may be related to the tidal zone habitat of most of the members of this family. This is borne out by the example of $C$. blanda (Thorson, 1940) and C. rustica (Franc, 1943). Petit and Risbec find about 20 eggs per capsule in C. flava of New Caledonia. Of these eggs only half the number undergo regular segmentation and the rest are unfertilised ones. In the present species there is an average number of 13 eggs per capsule. The egg is yellowish and measures $0.250 \mathrm{~mm}$. across. They appear to be suspended in a thick colourless nutritive fluid. Unfortunately the egg capsules were attacked by swarms of ciliates and further observation was made impossible. A few capsules examined showed that some of the eggs did not undergo segmentation at all and a few were in a state of disintegration. Further investigation is necessary to ascertain whether there are nurse eggs in this species.

Pyrene versicolor (Sowerby) (Photo 30 and Figs. 93-96).-The egg capsules belonging to Pyrene were collected from Manoli Island in the month of February 1955. They were attached to seaweeds. Pyrene versicolor appears to be quite common in the area examined and the egg capsules are therefore referred to this species. The apex of the adult shell also shows correspondence with the larval shell of the newly hatched veliger in the measurement of the 1st whorl, thereby adding weight to the identification.

The capsule is more or less circular or oval in outline. It is plano-convex and is white and transparent. The convex surface of the capsule shows a number of concentric ridges interlaced by disconnected radial ridges resulting in distinct pattern of rectangular spaces towards the periphery and a more or less reticulate netted appearance towards the top which appears to be due to the irregular folds of the wall of the capsule. The exit hole placed in the centre of the top of the capsule is elliptical and covered by a membrane which has highly wrinkled surface and appears superficially reticulate. The rim of the capsule is thickened and distinct. The basal plate or membrane appears to extend as a broad edge to the capsule. The capsule measures (excluding the edge) $1.80-2.00 \mathrm{~mm}$. The edge has a width of $0.22 \mathrm{~mm}$. The largest diameter of the exit hole is $0.609-0.696 \mathrm{~mm}$. 
The eggs are white and spherical and measure each $0.184 \mathrm{~mm}$. across. They are suspended in a colourless fluid. There are about 40-50 eggs in a capsule. All of them appear to develop into embryos. The eggs do not show normal development in the laboratory condition. Capsules containing embryos in the hatching stage however liberated the veligers. The newly hatched veliger measures $0.317 \mathrm{~mm}$. across the shell. The shell is fairly transparent and has one whorl. The velum is bilobed and colourless. Right lobe appears bigger. Sub-velum is present. Eyes are black. Tentacles are seen. Foot and operculum are present, the former is ciliated. Liver is yellow. Alimentary tract is purplish. Heart-beat is visible. The animal is yellow. The veliger thrived at the laboratory for 2 days.

The egg capsules attributed to Pyrene versicolor by Risbec (1929) and Amio (1955) seem to have different features from the present capsule. Possibly they belong to different species of Pyrene.

Pyrene zebra (Gray) (Photo 31 and Figs. 97-104).-The breeding habits of this species are described here for the first time.

The adult specimens of this species appear to be quite common in the gulf of Mannar in the areas between Vedalai and Mandapam. The present egg capsules collected from the same area seem to belong to Pyrene. The newly hatched veligers from the egg capsules show larval shells which agree with the apex of $P$. zebra in the measurement of the first whorl. Hence the present egg capsules are referred to the same species. The present egg capsules seem to belong to the type of $P$. misera.

The egg capsules may be laid isolatedly or attached to one another on the sides into a compact structure. They are oval or circular in outline and are plano-convex. Each has a distinct edge which appears to be the extension of the bottom membrane or plate. The surface of the capsule has a wrinkled appearance and shows vaguely in some of the freshly laid capsules 2-4 broken concentric lines towards the top. At the top of the capsule is present an elliptical exit hole which is covered by an opaque membrane. The membrane shows reticulated sculputre. Six of the capsules taken at random measure (excluding the edge of the capsule) $1.93 \times 1.76 \mathrm{~mm} ., 1.93 \times 1.71 \mathrm{~mm}$., $1.71 \times 1.60 \mathrm{~mm}$., $1.93 \times 1.82 \mathrm{~mm}$., $2.20 \times 1.88 \mathrm{~mm}$. and $2.15 \times 1.98 \mathrm{~mm}$. respectively. The edge of the capsule is $0 \cdot 28-0 \cdot 33 \mathrm{~mm}$. The exit holes in four capsules, taken at random, measure $0.77 \times 0.55 \mathrm{~mm}$., $0.66 \times 0.50 \mathrm{~mm}$, $0.66 \times 0.50 \mathrm{~mm}$. and $0.77 \times 0.66 \mathrm{~mm}$. respectively. The capsule seems to be attached to the substratum by the edge only. It is white and transparent showing clearly the developing embryos inside. 




FIGS, 103-121

The egg is white and spherical and measures $0.184 \mathrm{~mm}$. across. The number of eggs found in seven capsules are 22, 37, 36, 32, 29, 27 and 37 respectively. They appear to be suspended in clear colourless fluid. 
The embryo examined before hatching measures $0.283 \mathrm{~mm}$. across the shell which is thin and transparent and shows one whorl. The shell-siphon shows sculpture in the form of lines. The velum is bilobed. The right lobe is slightly bigger than the left. The velar lobes show bluish pigmentation along the margin. This pigmentation is more or less indistinct and only seen in closed light. There is a sub-velum with short cilia. Eyes are black and distinct. Only right tentacle is seen. The foot has a characteristic shape and is ciliated. It also shows a few long hairs at the distal end. The operculum is quite large and white. The otocysts are distinct. The internal organisation of the larvæ is not yet differentiated. Heart-beat is visible.

In the day-old veliger the disparity in the size of the lobes is quite marked. Eyes are prominent. Both tentacles are present. They also show a few hairs at the tip. In the area between the tentacles there is a patch of bluish pigmentation. The foot also shows on the left basal margin a patch of bluish pigmentation. The shell now measures $0.334 \mathrm{~mm}$. The outer-lip of the shell is slightly inflexed in the middle. The shell also shows a distinct spiral line besides transpiral striations. The internal organisation of the larvæ is now differentiated. The liver is golden yellow. The alimentary tract shows a patch of bluish pigmentation immediately after the stomach which also shows a few bluish dots. This feature is clear in some of the larvæ, vague and indistinct or absent in others. The 2-day veliger shows further growth and now measures $0.350 \mathrm{~mm}$. The well-developed velum suggests that the larva may have a long pelagic life.

Pyrene sp. (Photo 32 and Figs. 105-108).-The egg capsules were found usually attached to the surface of the egg capsules of Murex virgineus var. ponderosa and Conus. They could not be referred to the species with certainty.

The capsules are usually laid close to each other. The edge of one capsule usually touches or overlaps the next. But in many cases capsules are quite apart from one another. The dome-shaped capsule is surrounded by a well-developed edge. It appears to be fixed to the substratum mainly by the edge as is evident from the fact that when the edge is detached from the substratum the entire capsule comes off without difficulty. The capsule is white or colourless, thin and transparent revealing the eggs inside. It is not smooth but shows a wrinkled surface as though it is shrunk. It may be round, or oval in shape. In or around the centre of the capsule there is a preformed exit hole of a diameter of about $0.35 \mathrm{~mm}$. It is round or elliptical and is covered by a thin membrane. The largest diameter of the capsule (including the edge) is $2.05-3.05 \mathrm{~mm}$. Two faint ridges run in opposite 
directions from the centre of the capsule towards the periphery. In some the ridges are vague. In the following table the number of eggs in relation to the largest diameter of the capsule is given for a few capsules.

TABLE I

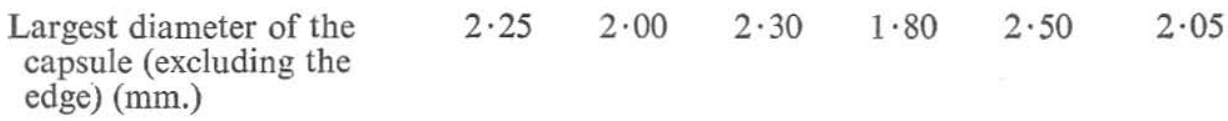

$\begin{array}{lllllll}\text { Number of eggs per capsule } & 88 & 77 & 90 & 61 & 103 & 82\end{array}$

The eggs are spherical, yellowish or brownish yellow and are found all over inside the capsule. They are surrounded by a thick white fluid which is used by the growing embryos. The egg (preserved material) measures $0.133 \mathrm{~mm}$. across.

The newly hatched veligers measure each $0 \cdot 233-0 \cdot 250 \mathrm{~mm}$. across the shell. The larval shell is smooth, colourless and fairly transparent. The shell-siphon is present. The animal is pale yellow. The velum is thick, bilobed and bordered with long cilia. The sub-velum is distinct with small cilia. Only the right tentacle is present and has fine hairs at the distal end. The left tentacle is not yet developed. The foot is ciliated. The two statocysts are distinctly seen. The operculum is present. The liver is brownish yellow. The alimentary tract appears bluish. The stomach is ciliated. The tissue near the anal area is brownish blue. The heart-beat is visible.

The membrane covering the exit hole gives way for the larvæ to come out. The newly hatched veligers swim about quite actively. They remained alive at the laboratory for four days but no visible changes could be noticed during the time. The well-developed velum points to the long pelagic period of larval life.

\section{Nassida}

The egg capsules of various species of Nassa are known in the literature (Lamy, 1928; Ankel, 1929; Lebour, 1931, 1937; Vestergaard, 1935; Risbec, 1935). Nothing is known of the breeding habits of Nassa from Indian waters.

Nassa jacksoniana (Quoy and Gaimard) (Photo 33 and Figs. 109-113).The breeding habits of this species are described here for the first time.

This is the commonest species of Nassa found abundantly in certain areas in the mud flats at Kundugul Point. Large numbers of this species 
were also observed at Watchman's Bay on Krusadai Island and Pamban (Satyamurti, 1952). At low tide patches of water are left behind here and there while large areas are exposed in the mud flat and on the edge of these small puddles of water the adult specimens are found in large numbers moving about actively. These forms are easily kept at the laboratory for three to four months; only it requires changing of water once in two or three days.

The snails deposited the egg capsules on the sides of the glass trough in the months of January (salinity $35 \cdot 58 \%$, temperature $24 \cdot 5^{\circ} \mathrm{C}$.), February (salinity $33 \cdot 12 \%$, temperature $26 \cdot 5^{\circ} \mathrm{C}$.), March (salinity $31 \cdot 06 \%$, temperature $25 \cdot 8^{\circ} \mathrm{C}$.), April (salinity $32 \cdot 27 \%$, temperature $28 \cdot 2^{\circ} \mathrm{C}$ ), May (salinity $32 \cdot 36 \%$, temperature $28 \cdot 2^{\circ}$ C.), August (salinity $35 \cdot 68 \%$, temperature $26 \cdot 5^{\circ} \mathrm{C}$.) and December (salinity $29.07 \%$, temperature $25.0^{\circ} \mathrm{C}$.). It is very likely that the breeding in this species occurs all the year round. The egg capsules could not be collected from the field in spite of close examination of the possible substrata like the shells, seaweeds, etc., the main disadvantage being the smallness of the capsules. It is very likely that the breeding of this species in the field is identical as in the laboratory.

In this species, the egg capsules are laid singly, as in Nassa incrassatus (Cooke, 1895; Lebour, 1931). The capsules laid in glass trough are close to the surface of the water or below about the middle of the glass sides but not on the bottom. The animal lays conical capsules on a disc-shaped plate. This ground plate is whitish and transparent and helps in fixing the capsule to the substratum. This feature is identical with that described for Nassa mutabilis (Korschelt and Heider, 1936). The capsule has one side flattened, i.e., the side which is laid on the ground plate. The other side has a wrinkled surface and is colourless and transparent revealing clearly the developing embryos inside. The neck of the capsule is well defined and measures $0 \cdot 116$ $0.183 \mathrm{~mm}$. in length. The aperture of the neck at the end forms the preformed exit hole for the larvæ at the time of hatching. It measures $0 \cdot 300$ $0.367 \mathrm{~mm}$. across. It is circular or elliptical in outline. The top of the neck appears to be covered by a thin membranous lid which is thrown off at the time of hatching. The capsules laid on the sides of the glass trough have the aperture facing downwards. This will, without doubt, help the larvæ to come out quite easily. The length of the capstle (excluding the basal plate), and the largest breadth of the capsule (excluding the basal plate) are 1.00 $1.65 \mathrm{~mm}$. and $1 \cdot 35-2 \cdot 00 \mathrm{~mm}$. respectively. The number of eggs per capsule is $25-72$. The numbers of egg capsules laid by a few females are: $27,25,9$, $9,13,6,8$ and 8 respectively. The capsules are laid very quickly; the adults do not appear to take more than 2-4 minutes for a capsule. 
The eggs are yellowish, spherical and each meàsures $0 \cdot 150-0 \cdot 167 \mathrm{~mm}$. in diameter. They are suspended all over inside the capsule in a colourless nutritive fluid. It takes about 4 days from the time the eggs are laid to the time of hatching. The temperate species of Nassa seem to take a longer duration of time, i.e., 3-4 weeks from spawning to hatching (Pelseneer, 1911; Lebour, 1931). All eggs develop into embryos. Pelagic development appears to be the normal feature in Nassa (Lebour, 1937). But Risbec (1935) observes non-pelagic development in $N$. suturalis. In the present case, however, the development is pelagic.

The embryo examined at an early stage measures $0.154 \mathrm{~mm}$. across the shell. The shell is colourless, thin and transparent and is cup-formed. The velum is colourless and measures $0.175 \mathrm{~mm}$. across and is bordered with few long cilia on each side, the rest of the margin showing only small cilia. The eyes are present but both tentacles have not yet developed. The foot is ciliated. The otocysts are present. No other organs are distinguishable excepting the heart-beat.

The embryo in the hatching stage measures $0.233 \mathrm{~mm}$. across the shell. The animal is pale yellowish. The bilobed velum, foot, otocysts and operculum are clearly seen through the capsule. Only the right tentacle appears to be present. The embryos are moving actively inside the capsule till they leave through the aperture of the capsule.

The newly hatched veligers are very active as soon as they leave the capsule. It has a smooth transparent and unsculptured shell. The latter measures $0 \cdot 233-0 \cdot 250 \mathrm{~mm}$. across. The outer lip of the larval shell is slightly extended into a slender process in the middle. The velum is colourless and bilobed with long cilia bordering the margin. There is a sub-velum underneath with small cilia. In between there is a groove in which the food particles are collected and brought to the mouth. The eyes are black and distinct and only the right tentacle is well developed and the left one is comparatively small. Pelseneer (1911) observes such a feature of disparity of tentacles in Nassa reticulatus. The otocysts, foot and operculum are quite distinct. The foot is ciliated but the cilia are small and indistinct. Also it has few long hairs at its distal end. The tentacles bear a few long hairs at the tip. The heart-beat is visible through the shell. The liver is pale yellow.

The veliger thrived at the laboratory only for 3 days. During this period no visible changes could be noticed. The well-developed velum bordered with long cilia points to a long pelagic life for the larva.

Nassa costata Adams (Photos 34 \& 35 and Figs. 114-119).-The breeding habits of this species are described here for the first time. 
This species is found in large numbers in the mud flats at Kundugal Point and in certain places at Vedalai. Satyamurti (1952) has also observed this species from Krusadai Island. This species like Nassa jacksoniana has been kept at the laboratory for several weeks without difficulty. They spawned at the laboratory in the months of January (salinity $29 \cdot 61 \%$, temperature $24 \cdot 0^{\circ} \mathrm{C}$.), February (salinity $31 \cdot 94 \%$, temperature $26 \cdot 5^{\circ} \mathrm{C}$.) and March (salinity $31.06 \%$, temperature $25.8^{\circ} \mathrm{C}$.). It is very likely that the breeding in this species may occur all the year round as in the previous species. Both these species of Nassa are found in the same habitat.

The capsules are laid in rows. Number of such rows are laid parallel and close to each other. The adhesive bases of these capsules are confluent so that a single sheet of common base is formed. The entire structure looks like a slender ribbon with fine strands, each strand representing a row of capsules. These slender ribbons give off branches in a characteristic way on either side which may again ramify into finer branches. This pattern of arrangement of egg capsules has not been met with in any species of Nassa whose breeding habits are known. Unfortunately the entire structure of the egg mass could not be photographed as the ribbons are so delicate that they come off in bits while removing from the substratum.

The capsules appear to be made up of two convex faces which are fused on sides as well as on the top, leaving a broad edge on the top. On the proximal end they are joined by a basal plate which forms the base of the capsule. The capsules are more or less triangular in outline. There is no stalk. The wall of the capsule is colourless, smooth, thin and transparent revealing the egg inside. Each capsule contains only one egg unlike the previous species. There is no preformed exit hole or aperture. The shape of the capsule as well as the presence of only one egg per capsule recall Risbec's account (1935) of Nassa suturalis. In the latter species there is a long well-developed stalk, unlike the present one. The length, the breadth at the distal end and the breadth at the proximal end of the capsule are $0.45-0.55 \mathrm{~mm} ., 0 \cdot 35-0.55 \mathrm{~mm}$. and $0 \cdot 10-0 \cdot 20 \mathrm{~mm}$. respectively.

The three egg masses examined contained 671, 1,652 and 1,009 egg capsules respectively. The egg is yellowish, spherical and is placed in the centre of the capsule. It measures $0 \cdot 200 \mathrm{~mm}$. across. It is surrounded by a white albumen-like substance. The time of development from spawning to hatching is about 4 days.

The embryo just before hatching measures $0.283 \mathrm{~mm}$. across the shell. The larval shell is colourless, sculptureless and transparent. The velum is bilobed and measures $0.250 \mathrm{~mm}$. across. Eyes are black. Both the tentacles 
are seen. Foot, operculum and otocysts are present. The foot is ciliated. The internal organs are not yet clearly distinguishable.

The day-old veliger measures $0.317 \mathrm{~mm}$. across the shell which shows one whorl. The outer lip of the shell is extended forward in the middle. The velum measures about $0.300 \mathrm{~mm}$. across. The sub-velum is present with small cilia. The tentacles are well developed and show a few long hairs at the tip. The foot is extended in the middle at the free end into a tentacular process which shows long hairs at the tip. The course of the alimentary tract is clearly seen. The anterior part of the stomach is slightly purplish. Liver is yellow. Retractor is visible.

The seven-day old veliger measures $0.400 \mathrm{~mm}$. across the shell which is colourless and fairly transparent. The margin of the aperture is brownish. The outer lip of the shell is prominently extended in the middle. The shellsiphon is present. The velum is very well developed and now measures $0.551 \mathrm{~mm}$. across. The length of each velar lobe is $0.334 \mathrm{~mm}$. The tentacles are well developed. Eyes are black and prominent. The veliger thrived at the laboratory for 8 days.

$\checkmark$ Nassa thersites (Bruguière) (Photos $36 \& 37$ and Figs. $120 \& 121$ ).-The breeding habits of this species are described here for the first time.

This species is quite common in the Pamban area and numerous live specimens have been collected on the mud flats at Kundugal Point. They are also found on the sandy stretches at Watchman's Bay and Bushy Point on Krusadai Island. This species have been reared in the laboratory for months. About 20 adult specimens kept in the aquarium thrived for more than 7 months. They spawned at the laboratory in the months of July (salinity $33 \cdot 46 \%$, temperature $27 \cdot 0^{\circ} \mathrm{C}$.) and August (salinity $33 \cdot 86 \%$, temperature $27 \cdot 5^{\circ} \mathrm{C}$.).

In the laboratory the egg capsules were laid on the glass wall of the aquarium or upon the live or dead shells of Cerithidea fuviatilis. The four egg clusters examined contained 21,33, 30 and 64 capsules respectively. The egg clusters are laid in patches consisting of a few rows of capsules. Occasionally they are also laid singly. Each capsule appears to be made up of two convex faces which are fused on the sides as well as on the top as in Nassa costata. The capsule is broad at the top and gradually tapers downwards. There is no exit hole or aperture in the capsule. The capsule is white, smooth and transparent and contains only one egg. Each capsule is provided with a well-developed base by which the capsule is attached to the substratum. The base is thin and transparent. There is no stalk for the capsule. The length, the breadth of the capsule at the distal end, and the breadth of the 
capsule at the proximal end are $0.46-0.52 \mathrm{~mm} ., 0.43-0.60 \mathrm{~mm}$. and $0.23-$ $0.32 \mathrm{~mm}$. respectively.

The egg is yellowish and placed in the centre of the capsule. It measures $0.250 \mathrm{~mm}$. across. It is surrounded by a white transparent nutritive fluid. The time of development from spawning to hatching is about 4 days in the laboratory. The embryo in the hatching stage shows smooth, colourless and sculptureless shell of a diameter of $0.317 \mathrm{~mm}$. The velum, eyes, tentacles, otocysts, foot and operculum are clearly seen. The other details are not clear. The newly hatched veliger measures about $0.350 \mathrm{~mm}$. across the shell. The shell is still sculptureless. The animal is pale yellowish. The velum is colourless and well developed and has two equal lobes bordered with long cilia on the margin. Underneath the velum and close to its margin is present the sub-velum with short cilia. The eyes are black. The tentacles are long and very prominent with the tip bearing long hairs. They are of equal size unlike in $N$. jacksoniana. The foot is ciliated but the cilia are vague. It is extended distally into a slender process which bears at its tip long hairs. The operculum is colourless. The otocysts are clearly seen. The alimentary tract is pale purplish and hence could be clearly seen through the shell. The liver is yellowish. The heart-beat is visible. The veliger thrived at the laboratory for two days. The larva did not show much change from the newly hatched veliger excepting a slight growth in the larval shell, which measures $0.434 \mathrm{~mm}$. across. The outer lip of the shell is slightly extended in the middle and tends to curve inwards. It shows a brownish or pinkish brown tint and fine dots, the latter are visible only under high power. The velum measures $0 \cdot 418-0 \cdot 467 \mathrm{~mm}$. across. The well-developed velum denotes a long pelagic life for the larva.

\section{Olividae}

No details regarding the breeding habits of the members of this family seem to be available in the literature.

Ancilla sp. (Photo 38 and Figs. 122-125).-The present egg masses which appear to belong to the genus Ancilla have been collected from Kundugal Point in August and September. The capsules are laid on the surface of polychæte tubes. The entire egg mass is below the level of the soil. The capsule has a flat bortom with a distinct margin. It projects upwards in the form of a cone. The cone-like capsule appears to be made up of two distinct halves which are fused in the middle. The line of fusion which is very distinct breaks apart at the time when the young ones are ready to come out. The capsule is parchment-like and quite smooth with the largest diameter of $4 \mathrm{~mm}$., smallest diameter of $3.5 \mathrm{~mm}$. and height $2.5 \mathrm{~mm}$. It holds only 
one embryo surrounded by a thick white substance which is probably utilised by the developing embryo. Here the entire development including the larval stages takes place within the capsule and the young one comes out in the crawling stage. Thus the development is non-pelagic.

In the early stage the embryo measures $0.65 \mathrm{~mm}$. The shell is cupformed. The velum is represented by two appendages with the margin showing small cilia. Foot is present. The embryo itself is little differentiated and apparently only contained a yolky mass. At a later stage the embryo shows the characteristic shell which is elongate with a long narrow aperture. It does not show any sculpture and is whitish and smooth. It measures $1.169 \mathrm{~mm}$. The foot is thick and very well developed and measures $0.70 \mathrm{~mm}$. The velum is more or less a narrow colourless band bordered with small cilia. It measures $1.33 \mathrm{~mm}$. In the next stage the embryo loses the velum and comes out as the young gastropod. The young ones show a well-developed foot with more or less semi-lunar propodium with a longitudinal groove in the middle. The shell shows further growth and measures $1.90 \mathrm{~mm}$. The siphon is present. The animal crawls about slowly. It could not be kept at the laboratory for more than 24 hours. The time of development from the egg to the hatching could not be given but the egg mass that was collected on 8th August 1952 liberated the young ones on 20th August 1952.

\section{Vasidee (Turbinellida)}

Information on the spawn masses of the members of this family is available in the literature (Lamy, 1928; Risbec, 1931; Hornell, 1921; Chidambaram and Unny, 1947).

Xancus rapa (Lamarck) (Photo 39 and Figs. 126 \& 127).-Egg cases belonging to this species have been collected from Vedalai and Mandapam areas in the month of January, February, April, July and August.

The egg case is an elongated, loosely spirally twisted structure and is aptly compared to a miniature ram's horn by Hornell (1921). It has a base by which it is attached to the sandy substratum. Each egg case is really a compound capsule as it is made up of distinct chambers or capsules. The chamber has a dome-shaped upper part and a thin-walled floor which is surrounded by a broad edge. Each chamber is a separate unit placed one above the other. They are attached to a membrane on one side and free on the opposite side. The floor of one capsule fits in compactly on the dome of the lower capsule. In the floor of each chamber is present a crescentic or nearly straight slit. This slit is probably the preformed exit passage. It varies in length and 




FIGS. 122-146

measures $5-15 \mathrm{~mm}$. It is covered by a thin transparent membrane. The chambers are not of uniform size. The chambers at the proximal end are small and increase gradually in size upwards till about $\frac{3}{4}$ of the egg case and afterwards there is a slight decrease (not very appreciable) in size up to the 
end. Usually 7-8 chambers from below and 2-4 from above do not hold any embryos. The breadth of the chamber varies between 1.3 and $2.8 \mathrm{~cm}$. The length measurements of three egg cases are $22 \mathrm{~cm} ., 28 \cdot 2 \mathrm{~cm}$., and $29 \cdot 5 \mathrm{~cm}$. respectively. The total number of chambers for three egg cases are 28,33 and 36 .

Egg cases at early stages of development could not be collected. On an average, each egg case produces 122 surviving young ones. The young ones at the time of examination showed about 4 whorls. The first $3 \frac{1}{2}$ whorls form the larval shell and the rest beginning to show the adult features. The first $3 \frac{1}{2}$ whorls do not show any sculpture. They are smooth, plain and colourless. The last whorl begins to show few pinkish brown spots. It also shows very feeble spiral striations. The shell-siphon is distinct. The aperture is elongate. In the specimens studied the young ones were in the withdrawn condition with the foot slightly pushed out. The operculum is brownish in colour. The foot also shows some pinkish spots. The shell measures about $9 \mathrm{~mm}$. in length and $3 \mathrm{~mm}$. in breadth. The young ones thrived at the laboratory for a day.

\section{Conida}

The egg masses of several members of this family have been described from other countries (Lamy, 1928; Petit and Risbec, 1929; Risbec, 1931, 1932; Thorson, 1940; Lebour, 1945; Knudsen, 1950; Ostergaard, 1950). Not much is known of the breeding of Conus from Indian waters excepting brief accounts by Hornell (1922) and Gravely (1942).

Conus araneosus Hwass. (Photos 40 \& 41 and Figs. 128-32).-The breeding habits of this species are described here for the first time.

This species appears to be quite common at Ceylon from where numerous shells are obtained to be sold as ornamental paper weights. It has been recorded at Pamban (Satyamurti, 1952). Numerous live specimens of this species have been collected from the Gulf of Mannar at Vedalai, Seeniyappa Dharuga and Mandapam. The adult specimens laid the egg masses at the aquarium on 25th January 1955 . They were found attached to the glass of the aquarium close to the bottom, the temperature and salinity being $24 \cdot 8^{\circ} \mathrm{C}$. and $29 \cdot 22 \%$ respectively. The animal of a length of $4.7 \mathrm{~cm}$. and breadth of $2 \cdot 7 \mathrm{~cm}$. took about 2 days to lay an egg mass of 45 capsules.

Gravely (1942) figures a mixed egg cluster from Madras probably laid by two closely allied species. He observes that they may belong to the genus Conus or to one of the other families of Toxoglossa. The figure as well as the few details given by him agree broadly with the present kind of egg mass and hence may be referred without doubt to a species of Conus. 
The breeding of the present species has been observed in the months of October, November, December, January, February and March.

The egg clusters collected from the field (Vedalai) were not attached to any substratum at the time of collection. Each capsule is a compressed pouch. It is white or pale-yellow. It is slightly curved, the bend being more pronounced generally towards the lower part of the capsule. The convex face of the capsule appears rugged made up of a number of elevations and depressions. There are also two or three fairly pronounced ridges on the same face running from the top towards the base. On the concave side there are two somewhat inwardly curved ridges that extend downwards from the upper angles. These ridges, however, are vague. Excepting these ridges this face is plain and smooth. The developing embryos are seen clearly through the exit passage which is located on the top of the capsule in the form of a slit and is covered by a thin, transparent, hyaline membrane. It almost occupies the entire top of the capsule and measures 4-6 mm. This type of exit passage very nearly corresponds to that of Conus mercator (Knudsen, 1950). The hyaline membrane dissolves at the time of hatching of the larvæ. The wall of the capsule is semi-transparent and gives a blurred view of eggs or embryos inside. It has a base which is very thin and papery and measures $8-11 \mathrm{~mm}$. across. The length as well as the largest breadth of the capsule are 9-17 mm. and $5-11 \mathrm{~mm}$. respectively. The number of embryos per capsule is 63-214. The average length, breadth and number of eggs for a capsule are $14.5 \mathrm{~mm}$., $9 \mathrm{~mm}$. and 164 respectively. The egg mass appears outwardly to consist of a bunch of compact capsules. On a closer scrutiny these capsules appear to conform to some pattern of arrangement. Thus there appears to be a bottom layer of capsules. These capsules bear on their convex surfaces a second layer of capsules, which in turn bear the third layer and so on.

The unsegmented egg is spherical and yellowish measuring 0.467$0.517 \mathrm{~mm}$. across. The eggs are scattered all over inside the capsule, being suspended in a white slimy nutritive fluid. The growing embryos not only make use of the nourishment contained in the eggs but also seem to devour the nutritive fluid surrounding them and grow to a remarkable size.

Among the species of Conus the development may be pelagic or nonpelagic, thus pelagic in C. hebrceus, C. capitaneus and many others ( $c f$. Risbec, 1931; Thorson, 1940; Lebour, 1945) and non-pelagic in C. mercator (Knudsen, 1950). In the present species, however, it appears to be pelagic. The embryo examined at the early stage measures $0.651 \mathrm{~mm}$. across the shell. The velum is very small and bilobed and measures $0.334 \mathrm{~mm}$. across. It is bordered with small cilia at the margin. It is pushed towards one side. The 
eyes and otocysts are present. The tentacles are not yet developed. The foot is small. The larva is little differentiated. The embryo examined a few days later showed the well-developed velum. The shell measures about $0.684 \mathrm{~mm}$. across. It is colourless and sculptureless with the shell-siphon just appearing. The velum is bilobed, the lobes being almost equal. It now measures $0.617 \mathrm{~mm}$. across. The sub-velum is not yet distinct. The eyes and tentacles are present though not well developed. The foot and operculum are present. The otocysts are quite small but fairly clearly seen. The embryo itself is still little differentiated. The anterior part of the alimentary tract is vaguely seen. Heart-beat is visible.

The larva at the next stage is further developed in many respects. The larval shell shows further increase in size measuring $0 \cdot 800-0 \cdot 850 \mathrm{~mm}$. across. The velum has grown still bigger and measures $0.935 \mathrm{~mm}$. across. It has a tendency to form four lobes. The sub-velum is now clearly seen. The eyes and tentacles are more prominent. The foot and operculum also show increase in size correspondingly. The otocysts are not clearly seen as in the younger stage. The internal organisation of the larvæ is not yet differentiated.

The hyaline membrane covering the exit passage gives way at the time of hatching. The embryos did not hatch out at the laboratory condition. The larvæ about to hatch out were dissected out from the capsule and kept in the finger bowl. They thrived for 36 hours. The larval shell now measures $1.10 \mathrm{~mm}$. and the velum $1.75 \mathrm{~mm}$. The velum is now distinctly four-lobed. The foot also shows increase in size comparatively. The larvæ swim as well as crawl, the latter feature probably denotes a short pelagic period.

Conus sp. (Photos $42 \& 43$ and Figs. $133 \&$ 134).-The present egg clusters have been referred to the genus Conus on the basis of the identification of similar capsules by Gravely (1942) from Madras. They could not be referred to the species with certainty. They have been collected from the mud flats at Kundugal Point in the month of August.

The capsules are strung together into a bunch but conform to a particular pattern of arrangement. The arrangement in one of the egg clusters is as follows: One of the capsules forms more or less the substratum for the entire bunch of capsules. This bears four capsules on one of its faces. Only two capsules of the four bear a batch of capsules on their faces, one of them bearing a row of four and the other seven. Again only one of the seven capsules bears a row of five capsules. Thus altogether there are 21 capsules. Similar arrangement with slight modifications has been found in the other egg cluster consisting of 13 capsules. The egg clusters of this species thus differ very much in the arrangement of capsules from those of $C$. araneosus whose pattern 
of arrangement is altogether different. The arrangement of capsules in the latter makes the egg cluster quite compact unlike the present one where it is loose.

The capsules which are compressed and pouch-like are strung into a bunch. They are pale yellowish in colour. Each capsule has a well-defined base. The base is thin and papery. The length of the capsule is $3-3 \cdot 2 \mathrm{~cm}$. and largest breadth $1 \cdot 8-2 \cdot 1 \mathrm{~cm}$. The capsule is covered by a network of ridges which are found on both faces. A pair of ridges on one face of the capsule but not on the other and quite distinct from others extend obliquely downwards from the upper angles. The exit passage is not preformed but the top of the capsule slits open at the time of the emergence of the larvæ. This slit or the exit passage measures $1 \cdot 4-1 \cdot 8 \mathrm{~cm}$. The number of eggs per capsule seems to be in hundreds (the exact number could not be given) and they are suspended all over inside the capsule in the colourless slimy fluid. All the eggs develop into embryos.

The egg clusters which were collected on 8th August 1952 liberated the veligers on 15th August. The embryo in the hatching stage measures $0 \cdot 200$ $0.233 \mathrm{~mm}$. across the shell which is cup-formed. The velum is bilobed, bordered with small cilia. It shows a few greenish pigment spots in each lobe. Foot and otocysts are clearly visible but eyes and tentacles are not seen. The embryo is little differentiated and apparently only contained a yolky mass. The veliger of two days old shows a well-developed bilobed velum, the lobes being almost equal in size and shape. The velum measures $0.250 \mathrm{~mm}$. across. The greenish pigment dots in each lobe are more prominent. Eyes and tentacles are now seen. The foot and operculum are present. The otocysts are indistinct unlike in the previous stage. The shell is thin and fragile and measures $0.250 \mathrm{~mm}$. across. The internal organs of the larvæ are not yet distinguishable excepting for the heart-beat. The veliger could not be kept at the laboratory for more than 4 days and during this period no further changes in them could be noticed. Larvæ may have a long pelagic life as is seen from the size of the velum.

Egg capsule A. (Photos 44 \& 45 and Figs. 135-139).-The egg capsules of the present type have been referred to the genus Conus by Gravely (1942) and Hemifusus by Habe (1944). Further investigation is required to refer the egg mass with any certainty to the genus and species.

The egg clusters have been collected from Gulf of Mannar around Mandapam, Seeniyappa Dharuga and Vedalai in the months of October (temperature $28^{\circ} \mathrm{C}$., salinity $36 \cdot 76 \%$ ), November (temperature $27^{\circ} \mathrm{C}$., salinity $32 \cdot 54 \%$ ), December (temperature $26 \cdot 1^{\circ}$ C., salinity $29 \cdot 69 \%$ ), January 
(temperature $24^{\circ} \mathrm{C}$., salinity $30 \cdot 75 \%$ ), February (temperature $25 \cdot 3^{\circ} \mathrm{C}$., salinity $29 \cdot 33 \%$ ), and March (temperature $27 \cdot 3^{\circ} \mathrm{C}$., salinity $31 \cdot 42 \%$ ). They were usually found attached to the shells of the live specimens of Xancus rapa. The six egg clusters examined showed 41, 45, 29, 25, 34 and 37 capsules respectively.

The capsule is compressed and pouch-like. It has fairly well pronounced depression on one side in the middle towards the upper end bounded by two well-pronounced inwardly curved ridges which extend downwards from upper angles. The other face is smooth without ridges. The top is slightly bowed seen from above. The wall of the capsule is tough, pale yellowish and semitransparent. The compressed capsules are placed side by side with the broad sides opposite and parallel to each other. The measurements of the capsule are the following: total height (from the substratum to the extremest part of the top border) $19-30 \mathrm{~mm}$.; height of the peduncle $1.75-4.25 \mathrm{~mm}$. ; largest breadth of the capsule 14-20 mm.; smallest breadth of the capsule $5.9 \mathrm{~mm}$. Each capsule has a distinct base by which they are glued to the substratum. The bases of the capsules are usually laid so close to each other that they form a long narrow sheet from which the capsules seem to arise. The top of the capsule has a well-defined preformed exit hole which is covered by a thin membrane. The exit hole is oblong or elliptical and measures $2-2 \cdot 5 \mathrm{~mm}$. across. The number of embryos per capsule is 54-119.

The unsegmented eggs are quite large, spherical and yellowish, each measuring $0.700-0.750 \mathrm{~mm}$. across. Almost in each capsule one to few eggs remain undeveloped. The eggs are scattered all over inside the capsule, being suspended in a colourless slimy fluid-probably consisting of albumen. The embryo, without doubt, devours the fluid and grows inside the capsule to a size much larger than that for which the nourishment contained in the egg itself could suffice.

The embryos did not hatch out in the laboratory condition. However the larvæ in the hatching condition were dissected out from the capsules and kept in finger bowl for examination. They measure $0.95-1.45 \mathrm{~mm}$. Of this range, the larvæ measuring $1 \cdot 25-1 \cdot 45 \mathrm{~mm}$. form $85 \%$ and appear to be normal development. Comparatively judging the larvæ measuring $0.95 \mathrm{~mm}$. appear to be sub-normal and form about $1 \%$ of total larvæ on an average. It is not possible at the moment to attribute any reasons for the apparent disparity in growth among the larvæ.

The larva which measures $0.95 \mathrm{~mm}$. has just more than one whorl. The yelum appears to be bilobed with a slight indentation in the middle. The 
eyes and tentacles are not clear. The foot and operculum are seen. The embryo is little differentiated.

The larvæ measuring $1 \cdot 25-1 \cdot 45 \mathrm{~mm}$. across the shell have each about 2 whorls, the second whorl showing characteristic sculpture consisting of longitudinal lines. The first whorl is sculptureless. The shell also shows a welldeveloped shell-siphon. The velum is distinctly four-lobed and colourless, each lobe being long and narrow. The cilia bordering the margin of the velar lobes are quite short. The eyes and tentacles are present but appear quite small. The otocysts are not distinct. The foot and operculum are present, the former being slightly darkish. The internal organs of the larvæ are not yet clear. Heart-beat is visible. The larvæ swim as well as crawl, the latter feature denoting their short pelagic life. The larvæ thrived at the laboratory for about 12 hours.

Egg capsule B. (Photos 46 \& 47 and Figs. 140-146).-The egg masses of this species have been observed at Vedalai, Seeniyappa Dharuga and Mandapam in the months of December, January, February and March. It appears that the breeding in this species may begin from October as in the previous species and range for six months.

The egg capsules were generally found attached to the shells of the live specimens of Xancus rapa. Occasionally wooden planks or twigs blown into the sea from the land also form the substrata. The nine egg clusters examined show 27, 33, 54, 31, 27, 25, 24 and 28 capsules respectively. The capsule is compressed and pouch-like and is uniformly flat except for a depression in the middle on one face towards the top end bounded by two distinct inwardly curved ridges which extend downwards from upper angles. One of the incurving ridges is slightly longer than the other. There are no ridges on the other face of the capsule. The top of the capsule is not straight but slanting as seen from above. The capsules are pale yellowish and semi-transparent. The measures of the capsule are the following: Total height (from the substratum to the extremest part of the top border) 16-20 mm.; height of the peduncle $2 \cdot 25-3.25 \mathrm{~mm}$.; largest breadth of the capsule 7-9 mm.; smallest breadth of the capsule 2.5-4 mm. Each capsule has a well-developed base. A well-defined preformed exit hole is present on the top border covered by a thin membrane. It may be close to the centre or towards one side (inside the ridge). The exit hole measures $1.5-1.9 \mathrm{~mm}$. The number of embryos per capsule is 39-84.

The eggs (undeveloped ones) are spherica!, yellowish and quite big each measuring $0.601 \mathrm{~mm}$. They are scattered all over inside the capsules in a 
thium morus), peculiar sand encrusted collar-like structures (Natica marochiensis), large slimy wavy bands (Tonna dolium) and capsules of various shapes and sizes (Murex virgineus var. ponderosa, Thais bufo, Nassa jacksoniana, Ancilla sp., Conus araneosus, etc.). In the holo-pelagic Ianthina prolongata, the egg capsules are suspended underneath the float. The capsules are usually parchment-like but in the genus Nerita ( $N$. albicilla in the present study), they are calcareous (excepting the base which is membranous). In primitive prosobranchs like Cellana sp. (not included in the present paper) the eggs are extruded singly in hundreds and fertilisation is external. There are also known in the literature cases of viviparity. Brood protection has been noted in the cowry Erronea errones. This appears to be the case in all the true cowries. In the nun cowry, Trivia monacha, the animal bites holes in the compound ascidians into which the vase-shaped egg capsules are embedded (Lebour, 1937).

Larval feeding and development.-Embryos with non-pelagic development may feed in different ways. Thus the large yolky eggs sufficiently rich in food may support the whole development up to the bottom stage, e.g., Lacuna pallidula (Pelseneer, 1911). In others the yolky eggs are further surrounded by a thick sheet of nutritive substances as in Ancilla sp. of the present study. In all species with these types of feeding the embryonic development seems to be uniform in that the embryos leave the egg capsules after reaching a certain size and organisation. Thus all the hatching young of the same species will be at the same stage of development. This, however, is not the case when the embryos resort to nurse egg feeding. Eggs of more or less uniform size are laid together within a common egg space or capsule. Only some of the eggs develop into embryos while the rest subserve as nurse eggs for the developing ones. The latter will not hatch out until they have exhausted all the nurse eggs. Nurse eggs feeding need not necessarily lead to a non-pelagic development. This is exemplified by the present example of Murex virgineus var. ponderosa. It is now well known that the pelagic stage is the most sensitive period in the life-cycle of marine invertebrates and consequently large waste of larvæ occurs during this period (Thorson, 1946). This shows clearly the evolutionary significance of nurse egg feeding (Thorson, l.c.). The eggs which could develop into pelagic larvæ in primitive times under favourable conditions may under adverse conditions have differentiated into nurse eggs (probably unfertilised ones) and normal eggs, the former subserving as food to the latter, so that the embryos can spend the entire veliger stage (pelagic) inside the capsule and come out as young ones or they emerge out as advanced veligers for a short pelagic life. 
white slimy fluid which is probably of nutritive nature. In each capsule one or two eggs remain undeveloped. The embryos reach a remarkable size at the time of hatching.

The embryo examined on the 11th day after oviposition has shell which is about a whorl and measures $0.801 \mathrm{~mm}$. across. The larval shell begins to show some spiral as well as transpiral striations. The velum is colourless and bilobed but shows a tendency towards four lobes. The cilia bordering the velar lobes are very small. Eyes are small. Tentacles are seen. Foot and otocysts are present. The larva is little differentiated. The heart-beat is visible. The animal is yellow.

The embryo examined on the 18th day after oviposition has a velum which is four-lobed each lobe being long and narrow. Eyes and tentacle are seen. Foot is little blackish. Otocysts are present. The shell-siphon is present. The heart-beat is visible. The internal organs are not clear. The embryo is yellowish.

The larvæ about to hatch out were dissected out from the capsule and kept in the finger bowl for examination. They measure $1 \cdot 10-1 \cdot 43 \mathrm{~mm}$. across the shell. Of this about $90 \%$ of the larvæ measure $1 \cdot 32-1 \cdot 43 \mathrm{~mm}$. The smallest observed was $0.85 \mathrm{~mm}$. This forms a very small and negligible percentage. The larvæ measuring $1 \cdot 32-1 \cdot 43 \mathrm{~mm}$. have each two whorls. The second whorl has a characteristic sculpture consisting of longitudinal as well as spiral striations. The first whorl is almost sculptureless. The velum is well developed and colourless. It consists of four distinct velar lobes, the lobes being long and narrow. The cilia bordering the margin of the velar lobes are quite short. The eyes and tentacles are present. The foot and operculum are distinct. The otocysts are not clear. The larva is little differentiated yet and has a tendency to swim as well as crawl. The latter feature indicates the short pelagic life of the larva.

These larvæ lose their velar lobes and settle down in 2-3 days in the laboratory. The 8 -day-old young one measures $1 \cdot 45-1 \cdot 50 \mathrm{~mm}$. across the shell. The shell is slightly brownish and tentacles are prominent. Foot is well developed. The young ones crawl about the finger bowl. They thrived at the laboratory for 25 days. But no noticeable growth could be observed during the time.

\section{Discussion}

Oviposition.-The egg masses of marine prosobranchs are very characteristic in their shape and appearance. The following types have been met with in the present investigation: gelatinous ribbons (Cerithidea fluviatilis, Cerị 
It has been found in the Arctic marine prosobranch Sipho islandicus that the capsules with nearly the same quantity of nurse eggs may contain from 1-16 embryos. Naturally in the capsule holding 16 embryos, the embryos hatch out at a much earlier stage (though non-pelagic) than a single embryo contained in a capsule with plenty of food at its disposal (Thorson, 1935). Natica catena provides a fine example in which the development is pelagic at one place, i.e., Southern North Sea (Lebour, 1936) and non-pelagic at another place, i.e., Denmark (Thorson, 1946), in each case the development being determined by the amount of nurse eggs. Planaxis sulcatus reproduces without nurse eggs and with pelagic larvæ at New Caledonia (Risbec, 1935) and with nurse eggs and without pelagic development in the Iranian Gulf (Thorson, 1940). Similar is the case in Thais hamastoma (T. floridana) which reproduces without nurse eggs and with pelagic larvæ in Louisiana (Burkenroad, 1931) and with nurse eggs with non-pelagic development in West Indies (Lamy, 1928; Korschelt and Heider, 1936). A phenomenon of more or less similar type seems to exist within the genus Dolium. In Tonna dolium (Dolium maculatum) observed here, there seems to be no nurse egg feeding, as all the eggs develop into pelagic larvæ. Though similar mode of reproduction appears to be the case in this species from Iran, Thorson (1940) finds in a few egg spaces considerably large embryos which he suspects as may be due to nurse egg feeding or cannibalism.

The availability of nurse egg per embryo varies from a few to thousands, thus a few in Natica catena, i.e., 50 nurse eggs for 3 or 4 embryos (Ankel, 1930), 10-15 nurse eggs per embryo in Nucella lapillus (Lebour, 1937), 72-251 per embryo in Murex quadrifrons (Knudsen, 1950), about 2,500 in Neptunea antiqua (Thorson, 1946), about 7,000 per embryo in Sipho islandicus (Thorson, 1935 ) and 50,000-100,000 per embryo in Volutopsis norvegica (Thorson, 1940). In Murex virgineus var. ponderosa and $M$. trapa described here it is about 24 and 10 respectively. The method of devouring the nurse eggs is interesting in different species. Thus in Nucella lapillus (Thorson, 1946), each capsule contains some hundred eggs of which only a few develop, the rest forming nurse eggs. The nurse eggs fall to pieces and form a column of yolk in the middle of the capsule on which the embryos feed by sucking. In Buccinum undatum (Portman, 1925), as in the previous species, only a few develop out of some hundreds of eggs, the rest forming nurse eggs. The nurse eggs will not fall to pieces as in Nucella lapillus, but are quite intact when devoured. Knudsen (1951) finds identical phenomenon in Murex quadrifrons from West Africa. He observed that the embryo takes half an hour to swallow a nurse egg. In Murex virgineus var. ponderosa, a few egg capsules were cut open and the nurse eggs and larvæ were transferred to watch-glass 
for observation. It was found that the eggs are manipulated by the larvæ to the mouth by velar lobes and foot and pressed. The collapsed eggs are then sucked up in 2-3 minutes. This type of nurse egg feeding seems to be different from Nucella and Buccinum types.

Influence of temperature on pelagic development.-Thorson, from his investigations at East Greenland (1935), East Iceland, South Iceland, the Feroes (1941), Danish waters (1946) and Iran (1940) as well as from other places, has been able to arrive at the conclusion that the percentage of pelagic development increases from Arctic towards Equator. Thus the pelagic development in East Greenland is $0 \%$ (Thorson, 1935); East Iceland 10\%, South Iceland $30 \%$, Faroes 40\% (Thorson, 1941); British Isles 64\% (Lebour, 1937); Danish waters $65 \%$, Iranian Gulf $75 \%$ (Thorson, 1946, 1940); New Caledonia 57\% (Risbec, 1935). The investigations carried out since then also seem to support this view. Thus Lebour finds pelagic development in $90 \%$ of the prosobranchs of Bermuda (Lebour, 1945). The present investigations in India show about $91 \%$ of pelagic development, i.e., out of 33 species of prosobranchs [which includes Cymbium melo in which Hornell (1921) gives a brief account on development] only 3 species, namely Ancilla sp., Xancus rapa and Cymbium melo, have non-pelagic development. The prosobranchs of New Caledonia appear to show rather low percentage of pelagic development and those at Bermuda a little too high. In the case of New Caledonia, the material examined comprised mostly tidal zone forms which, generally, show a high percentage of non-pelagic development. In Bermuda the material exdmined is quite small and hence appears to show exaggerated percentage of pelagic development. Thorson (1940) is of the opinion that in the reproduction of prosobranchs of all oceans there is a tendency for the pelagic development to be totally suspended in the deep sea and restricted to shelf faunas, and that starting from the Arctic and Antarctic where the pelagic development is suppressed there is a gradual increase of the same towards the tropic shelves where it is the highest. The results obtained from tropical South-West Africa by Knudsen (1950) appear to present a different picture. The percentage of species having non-pelagic development in the region is about the same as in the waters of South and West Iceland. The investigations carried out along the Coast from off Sierre Leone to the Niger Delta show that this area is influenced by the Guinea current which is poor in the nutrient salts as well as plankton and brings about a strong exchange of water between the coastal and oceanic waters. It is therefore possible as suggested by Knudsen that the results obtained at South-West Africa are due to the spcial ecological peculiarities of the area examined, 
Breeding.-Anne Stephenson (1934), Panikkar and Aiyar (1939) and Paul (1942) have shown that there are different types of both continuous and discontinuous breeding in marine and brackish-water animals in tropical waters. Even though it was not possible to maintain the breeding record of the different species of prosobranchs under investigation all the year round, it could be said from the present observations that there exist both types of continuous and restricted breeding in the forms dealt with from the Gulf of Mannar and Palk Strait. No inference could be drawn regarding the effect of temperature and salinity on the breeding. These factors appear to influence the intensity of breeding in Ostrea madrasensis (Rao, 1951).

\section{SumMARY}

Egg masses and larval development are described for 32 species of prosobranchs from the Palk Bay and the Gulf of Mannar. The present observations throw light on the breeding biology of Cerithium morus, Cerithium sp., Natica tigrina, Natica spp., Tonna sp., Murex virgineus var. ponderosa, Murex trapa, Thais tissoti, Thais spp., Pyrene zebra, P. versicolor, Pyrene sp., Nassa jacksoniana, $N$. costata, $N$. thersites, Ancilla sp. and Conus araneosus, which are reported here for the first time. The existing knowledge of breeding in Nerita albicilla, Erronea errones and Pyrene flavida has been supplemented by observations from Indian waters. In the remaining species (Cerithidea fluviatilis, Ianthina prolongata, Natica marochiensis, Tonna dolium, Thais bufo and Xancus rapa) more details on the egg structure and development are given than are available in the literature.

Breeding range of the species under investigation was determined from the observations made on the field as well as in the laboratory. Continuous as well as seasonal breeding have been noted among the species studied. Salinity and temperature were noted wherever possible but their effect on breeding requires further study.

While most of the gastropodous egg masses are left uncared for by the parents which deposit them, in the Cowry Erronea errones there is protection of brood until the time of hatching of the larvæ. In Murex virgineus var. ponderosa and Murex trapa only a few eggs develop into embryos, the rest subserving as nurse eggs. Nurse egg feeding is followed in these two species by a short pelagic life. Pelagic development is preponderant and only in 2 of the 32 species studied is the pelagic stage completely suppressed.

\section{REFERENCES*}

1. Amio, M. I. J. Shimonoseki Coll. Fish., 1955, 4(2), 231-38.

2. Annandale, N. and Kemp, Mem. Ind. Mus., Calcutta, 1916, 5, 328-66,

S. 
3. Chari, V. K.

4. Chidambaram, K, and Unny, $M$.

5. Cooke, A. H.

6. Crichton, M. D.

7. Franc, A.

8. Giglioli, M. E: C.

9. Gravely, F. H.

10. Habe, T.

11.

12.

13. Harvey, H. W.

14. Hornell, J.

15. Kundsen, J.
.. J. Bombay Nat. Hist. Soc., 1950, 49, 317.

Proc. Zool. Soc. London, 1947, 117 (2/3), 528-32.

. Camb. Nat. Hist. Moll., 1895.

. J. Bombay Nat. Hist. Soc., 1941, 42, 323-41.

.. J. Conchyliol, 1948, 88 (1), 12-35.

.. J. Fish. Res. Bd. Canada, 1955, 12 (2), 287-327.

. Bull. Mad. Govt. Mus. (Nat. Hist.), 1942, 5 (2).

.. J. Conchology, .1944, 13 (5-8), 171-206.

.. Publ. Seto Mar. Biol. Lab., 1953, 3 (2), 161-67.

.. The Venus; Jap. Jour. Mal., 1955, 18 (3), 204-07.

.. Recent Advances in the Chemistry and Biology of Sea-water, 1945.

. Mad. Fish. Bull., 1921, 14, 97-210.

. Sci. Res. Dan. Exp. Coast of Trop. West Africa. Atlantide Rep., 1950, 85-128.

.. Hydrographical Tables, 1901.

17. Korschelt, E. und Heider, K.

Vergleichende Entwicklungsgeschichte der Tiere, 2 Band. (New bearbeitet von E. Korschelt), 1936.

18. Lamy, E.

19. Laursen, D.

20. Lebour, Marie, V.

21.

22.

23. Natarajan, A. V.

24. Ostergaard, J. M.

25. Panikkar, N. K. and Aiyar, Proc. Ind. Acad. Sci., 1939, 9 B, 343-64.

R. G.

. J. de Conchyliologie, 1928, Ser. 4, 72, 25-52, 80-126.

. Dana-Report, 1953 (38).

.. J. Mar. Biol. Assoc., 1936, 20 (3), 547-66.

. Ibid., 1937, 22, 105-66.

.. Proc. Zool. Soc., 1945, Pt. IV, 114, 462-89.

.. Curr. Sci., 1954, $23(7), 225-26$.

.. Pacific Sci., 1950, 4 (2), 75-115.

26. _- and Tampi, P. R. S. J. Bombay Nat. Hist. Soc., 1949, 48 (3), 598-99.

27. Paul, M. D.

.. Proc. Ind. Acad. Sci., 1942, 15, 1-42.

28. Petit, G. et Risbec, J.

29. Rao, K. V.

30. Rasmussen, Erik.

31.

32. Ray, H. C.

33. Risbec, J.

34.

35.

36.

37. Sadasivan, V.
.. Bull. Soc. Zool. Franc., 1929, 54, 564-70.

.. Proc. Ind. Acad. Sci., 1951, 33, 231-56.

.. Vid. Medd. Dansk. Naturh. Foren, 1944, 107, 207-33.

. Ibid., 1951, 113, 201-49.

. J. Bombay Nat. Hist. Soc., 1951, 49 (4), 663-69.

.. Bull. Mus. Hist. Nat., Paris, 1928.

.. Ann. Inst. Ocean., 1931, 10 (2), 23-33.

. Bull. Soc. Zool. Franc., 1932, 57 (4), 358-75.

. Ibid., 60 (5), 387-417.

.. Proc. 35th Ind. Sci. Cong. Abstracts, 1948, 198. 
38. Satyamurti, T.
39. Stephenson, A.
40. Thiele, J.
41. Thorson, G.
42. -
43. -
44.

45. Vayssière, A.

46.
.. Bull. Mad. Govt. Mus., 1952, 1 (2), pt. 6.

.. Great. Barr. Reef. Exped. Sci., 1934., Rep. 3, 247-72.

.. Handbuch der systamatischen Weichtierkunde, 1931.

.. Medd. Om. Gronland, 1935, 100 (5), 1-71.

. . Danish Scientific Investigations in Iran, 1940, pt. II, 159-238.

. Marine Gastropoda Prosobranchiata. Zoology of Iceland, 1941, 4, pt. $60,159$.

.. Medd. Komm. f. Danmarks Fiskeri og. Havunders, 1946, Serie: Plankton, Bind 4, Nr. 1.

.. Ann. Mus. Hist. Nat. Marseille, Zool., 1923, 18, 1-120.

.. Ann. Mus. Hist. Nat. Marseille, 1927, 21, 133-84.

* For other references, not included here but cited in the text, the reader is requested to consult the papers of Lamy (1928), Lebour (1937), Thorson $(1940,1946)$ and Knudsen (1950).

\section{EXPLANATION OF TEXT-Figures}

Text-Figs. 1-18. Figs. 1-6. Nerita albicilla. Fig. 1. Egg capsule. Fig. 2. Sculpture of the egg capsule enlarged. Fig. 3. Egg. Fig. 4. Newly hatched veliger, retracted into the shell. Fig. 5. Newly hatched veliger, swimming posture. Fig. 6. Day-old veliger, retracted. Figs. 7-9. Cerithidea fluviatilis. Fig. 7. Egg capsule showing the egg inside. Fig. 8. Embryo in the hatching stage with the velum and foot partly retracted into the shell. Fig. 9. Larval shell of the newly hatched veliger. Figs. 10-18. Cerithium morus. Fig. 10. Egg capsule showing the egg inside. Fig. 11. Embryo in the hatching stage. Fig. 12. Larval shell (left side) of the same. Fig. 13. Veliger larva, 1 day-old. Fig. 14. The same with the animal completely retracted into the shell. Fig. 15. Larval shell of the same (right side). Fig. 16. Veliger larva 4-day old. Fig. 17. Larval shell (right side) of the same. Fig. 18. Larval shell (left side) of the same.

Text-Figs. 19-40. Figs. 19-22. Cerithium sp. Fig. 19. Egg capsule showing the egg inside. Fig. 20. Newly hatched veliger with the velum and foot partly retracted into shell. Fig. 21. Larval shell (left side) of the same. Fig. 22. Two-day old veliger. Figs. 23 and 24. Ianthina prolongata. Fig. 23. Egg. Fig. 24. Newly hatched veliger. Figs. 25-30. Natica marochiensis. Fig. 25. Apex of the adult. Fig. 26. Vertical trans-section of the egg ribbon showing the eggs inside-only part of the section is shown. Fig. 27. Egg capsule showing the egg inside. Fig. 28. Newly hatched veliger. Fig. 29. Larval shell (left side) of the same. Fig. 30. Larval shell (right side) of the same. Figs. 31-35. Natica tigrina. Fig. 31. Apex of the adult. Fig. 32. Vertical trans-section of the egg ribbon showing the embryos inside (only part of the section is shown). Fig. 33. Newly hatched veliger. Fig. 34. Same with the animal completely retracted into the shell. Fig. 35. Larval shell (right side) of the same. Figs. 36-40. Natica sp. A. Fig. 36. Vertical trans-section of the egg ribbon showing the embryos inside (only part of the section shown). Fig. 37. Egg capsule showing the egg inside. Fig. 38. Newly hatched veliger. Fig. 39. The same with the animal partly retracted into the shell. Fig. 40. Larval shell (right side) of the same.

Text-Figs. 41-59. Figs. 41 \& 42. Natica sp. B. Fig. 41. Newly hatched veliger. Fig. 42. Larval shell (left side) of the same. Figs. 43-49. Erronea errones. Fig. 43. Egg capsule showing the eggs inside. Fig. 44. Egg. Fig. 45. Newly hatched veliger. Fig. 46. The same with the velum and foot partly retracted into the shell. Fig. 47. Larval shell (right side) of the same. 
Fig. 48. Sculpture of the larval shell. Fig. 49. Operculum of the larva. Figs. 50-54. Tonna dolium. Fig. 50. Apex of the adult. Fig. 51. Egg. Fig. 52. Newly hatched veliger. Fig. 53. Sculpture of the larval shell. Fig. 54. Operculum of the larva. Figs. 55-59. Tonna sp. Fig. 55. Egg. Fig. 56. Newly hatched veliger. Fig. 57. Larval shell (right side) of the same. Fig. 58. Larval shell (left side) of the same. Fig. 59. Sculpture of the larval shell.

Text-Figs. 60-81. Figs. 60-69. Murex virgineus var. ponderosa. Fig. 60. Egg. Fig. 61. Embryo at an early stage. Fig. 62. Embryo of a later stage. Fig. 63. Embryo about to hatch out. Fig. 64. Larval shell (ventral view) of the same. Fig. 65. Larval shell (dorsal view) of the same. Fig. 66. Sculpture of the larval shell. Fig. 67. Veliger, 2-day old


one, 20-day old. Figs. 70-78. Murex trapa. Fig. 70. Apex of the adult. Fig. 71. Egg capsule. Fig. 72. Egg. Fig. 73. Embryo at the time of hatching. Fig. 74. Larval shell (ventral view) of the same. Fig. 75. Larval shell (dorsal view) of the same. Fig. 76. Young one just settled down after $2 \frac{1}{2}$-days of larval life. Fig. 77. Shell of the young one, 2-day old. Fig. 78. Shell of the young one, 12-day old. Figs. 79-81. Thais bufo. Fig. 79. Newly hatched veliger. Fig. 80. Same with the velum partly withdrawn into the shell (right side). Fig. 81. Same with the animal nearly retracted into the shell (left side view).

Text-Figs. 82-102. Figs. 82-85. Thais tissoti. Fig. 82. Apex of the adult. Fig. 83. Embryo at the time of hatching. Fig. 84. Larval shell (right side) of the same. Fig. 85. Larval shell (ventral view) of the same. Figs. 86-88. Thais sp. A. Fig. 86. Embryo about to hatch out. Fig. 87. Larval shell (left side) of the same. Fig. 88. Larval shell (dorsa1 view) of the same. Fig. 89. Thais sp. B. Fig. 89. Newly hatched veliger with the velar lobes nearly retracted into the shell. Figs. 90-92. Thais sp. C. Fig. 90. Newly hatched veliger. Fig. 91. Larval shell (left side) of the same. Fig. 92. Larval shell (right side) of the same. Figs. 93-96. Pyrene versicolor. Fig. 93. Apex of the adult. Fig. 94. Egg. Fig. 95. Newly hatched veliger. Fig. 96. Larval shell (ventral view) of the same. Figs. 97-104. Pyrene zebra. Fig. 97. Apex of the adult. Fig. 98. Egg. Fig. 99. Embryo at the time of hatching. Fig. 100. Veliger, 1-day old. Fig. 101. Same with the animal fully retracted into the shell (right side view). Fig. 102. Two-day old veliger with the velum partly retracted into the shell.

Text-Figs. 103-121. Fig. 103. Larval shell (dorsal view) of the same. Fig. 104. Larval shell (ventral view) of the same. Figs. 105-108. Pyrene sp. Fig. 105. Egg. Fig. 106. Newly hatched veliger. Fig. 107. Larval shell (right side) of the same. Fig. 108. Larval shell (left side) of the same. Figs. 109-113. Nassa jacksoniana. Fig. 109. Egg. Fig. 110. Embryo at an early stage. Fig. 111. Embryo in the hatching stage. Fig. 112. Newly hatched veliger. Fig. 113. Larval shell (right side) of the same. Figs. 114-119. Nassa costata. Fig. 114. Egg. Fig. 115. Embryo just before hatching. Fig. 116. Nelwy hatched veliger. Fig. 117. Veliger, 1-day old. Fig. 118. Seven-day old veliger. Fig. 119. Larval shell of the same. Figs. 120121. Nassa thersites. Fig. 120. Newly hatched veliger. Fig. 121. Same with the animal partly retracted into the shell (left side view).

Text-Figs. 122-146. Figs. 122-125. Ancilla sp. Fig. 122. Egg capsule. Fig. 123. Embryo at an early stage. Fig. 124. Embryo at a later stage. Fig. 125. Crawling young one. Figs. 126 and 127. Xancus rapa. Fig. 126. Young one, with the animal almost retracted into the shell. Fig. 127. Shell of the young one (dorsal view). Figs. 128-132. Conus araneosus, Fig. 128. Egg. Fig. 129. Embryo at an early stage. Fig. 130. Embryo at a later stage. Fig. 131. Embryo at the next stage. Fig. 132. Larval shell of the same. Figs. 133 and 134. Conus sp. Fig. 133. Embryo at the time of hatching. Fig. 134. Veliger, 2-day old. Figs. 135-139. Egg capsule A. Fig. 135. Egg. Figs. 136 and 137. Sub-normal embryos at the time of hatching. Fig. 138. Normal embryo at the time of hatching. Fig. 139. Larval shell of the same. Figs. 140-146. Egg capsule B. Fig. 140. Egg. Fig. 141. Embryo 11 
days after oviposition. Fig. 142. Embryo 18 days after oviposition. Fig. 143. Embryo about to hatch out. Fig. 144. Larval shell of the same. Fig. 145. Sculpture of the larval shell. Fig. 146. Eight-day old young one.

\section{EXPLANATION OF PHOTOGRAPHS}

\section{Plate XIV}

Рното 1. Egg ribbons of Cerithidea fluviatilis.

Рното 2. Photomicrograph of a small area of the egg ribbon of C. fluviatilis showing the embryos and their surrounding capsules. ca., $\times 26$.

Рното 3. Newly laid egg ribbon of Cerithium morus.

Рното 4. Photomicrograph of a small area from one side of the egg ribbon of C. morus showing the eggs and their surrounding capsules. ca., $\times 18$.

Рното 5. Egg ribbons (disturbed while dislodging from the substrata) of Cerithium sp.

Pното 6. Photomicrograph of a small area of the egg ribbon of Cerithium sp. ca., $\times 24$.

Рното 7. Float of Ianthina prolongata showing the egg capsules underneath.

Рното 8. Individual egg capsule of Ianthina prolongata. Nat. size. $5 \mathrm{~mm}$. in length.

Рното 9. Egg ribbon of Natica marochiensis.

Рното 10. Egg ribbon of Natica tigrina.

Рното 11. Egg ribbon of Natica sp. A.

Рното 12. Egg mass of Erronea errones.

Рното 13. Photomicrograph showing the arrangement cf the egg capsules in Erronea errones. ca., $\times 8$.

Рното 14. Egg ribbon of Tonna dolium.

\section{Plate XV}

Рното 15. Photomicrograph of a small area of the egg ribbon of $T$. dolium showing the egg capsules and embryos. ca., $\times 7 \frac{1}{2}$.

Рното 16. Egg ribbon (only part of it) of Tonna sp.

Pното 17. Photomicroøraph of a small area of the egg ribbon of Tonna sp. showing the semilunar arrangement of the eggs in each capsule. ca., $\times 7 \frac{1}{2}$.

Pното 18. Same showing the embryos in each capsule. ca, $\times 6 \frac{1}{2}$.

Рното 19. Egg cluster of Murex virgineus var. ponderosa.

Pното 20. Egg cluster of Murex trapa.

Рното 21. Egg cluster of Thais bufo.

Рното 22. A few individual capsules of the same.

Pното 23. Egg cluster of Thais tissoti.

Pното 24. Two individual capsules (photomicrograph) of the same, showing the embryos inside. ca., $\times 9 \frac{1}{2}$.

Рното 25. Egg cluster of Thais sp. A.

Рното 26. Egg cluster of Thais sp. B. 
Рното 27. Egg capsule (photomicrograph) of Thais sp. C. Nat. size ca., $3 \cdot 5 \mathrm{~mm}$. in length, Рното 28. Egg mass of Pyrene flavida.

Рното 29. Individual capsule (photomicrograph) of the same. Nat. size $2.5 \mathrm{~mm}$. in length. Рното 30. Egg capsule (photomicrograph) of Pyrene versicolor. Nat. size. ca., $2 \mathrm{~mm}$.

Рното 31. Egg capsules (photomicrograph) of Pyrene zebra. Nat. size. ca., $2 \cdot 2 \mathrm{~mm}$.

\section{Plate XVI}

Рното 32. Egg capsules (photomicrograph) of Pyrene sp. ca., $\times 9 \frac{1}{2}$

Рното 33. Egg capsule (photomicrograph) of Nassa jacksoniana showing the eggs inside. ca, $\times 13 \frac{1}{2}$.

Рното 34. Part of an egg mass (photomicrograph) of Nassa costata showing the embryos inside. ca., $\times 21$.

Рното 35. An individual capsule (photomicrograph) of the same showing the egg inside. ca., $\times 74$.

Рното 36. Part of an egg mass (phetomicrograph) of Nassa thersites showing the embryos inside. ca., $\times 17 \frac{1}{2}$.

Рното 37. An individual capsule (photomicrograph) of the same showing the egg inside. ca., $\times 55$.

Рното 38. Egg capsules of Ancilla sp. attached to a polychæte tube.

Рното 39. Egg case of Xancus rapa.

Рното 40. Egg cluster of Conus araneosus.

Рното 41. Individual capsules of the same.

Рното 42. Egg cluster of Conus sp.

Рното 43. Individual capsule of the same showing the sculpture and exit slit at the top.

Рното 44. Egg cluster of egg capsule A.

Рното 45. Individual capsule of the same.

Рното 46. Egg cluster of egg capsule B.

Рното 47. Individual capsule of the same. 